\title{
Bimodal magmatism as a consequence of the post-collisional readjustment of the thickened Variscan continental lithosphere (Aiguilles Rouges-Mont Blanc Massifs, Western Alps)
}

\author{
François Bussy, Jean Hernandez and Jürgen Von Raumer
}

\begin{abstract}
High Precision U-Pb zircon and monazite dating in the Aiguilles Rouges-Mont Blanc area allowed discrimination of three short-lived bimodal magmatic pulses: the early $332 \mathrm{Ma}$ $\mathrm{Mg}-\mathrm{K}$ Pormenaz monzonite and associated $331 \mathrm{Ma}$ peraluminous Montées Pélissier monzogranite; the $307 \mathrm{Ma}$ cordierite-bearing peraluminous Vallorcine and Fully intrusions; and the $303 \mathrm{Fe}-\mathrm{K}$ Mont Blanc syenogranite. All intruded syntectonically along major-scale transcurrent faults at a time when the substratum was experiencing tectonic exhumation, active erosion recorded in detrital basins and isothermal decompression melting dated at 327-320 Ma. Mantle activity and magma mixing are evidenced in all plutons by coeval mafic enclaves, stocks and synplutonic dykes. Both crustal and mantle sources evolve through time, pointing to an increasingly warm continental crust and juvenile asthenospheric mantle sources. This overall tectono-magmatic evolution is interpreted in a scenario of post-collisional restoration to normal size of a thickened continental lithosphere. The latter re-equilibrates through delamination and/or erosion of its mantle root and tectonic exhumation/erosion in an overall extensional regime. Extension is related to either gravitational collapse or back-arc extension of a distant subduction zone.
\end{abstract}

KEYWORDS: Acid-basic, exhumation, extension, granite, migmatites, syntectonic intrusion, $\mathrm{U}-\mathrm{Pb}$ dating, zircon.

The Variscan belt of Europe resulted from the complex and polycyclic collision of two supercontinents, Laurasia to the $\mathrm{N}$ (i.e. Baltica together with Laurentia and Avalonia) and Gondwana to the S, separated by the Rheic ocean in the Early Ordovician. Of the many and often contradictory geodynamic scenarios suggested, that of Stampfli (1996) proposes that the progressive subduction of this oceanic domain below the northern margin of Gondwana initiated the Early Silurian back-arc opening of the Palaeotethys ocean, and progressive drifting of a narrow continental ribbon, the so-called 'Hun composite superterrane'. The northward relative motion and slight anticlockwise rotation of Gondwana progressively closed the Rheic ocean along the northern front of the Variscan belt (Late Devonian?, Faure et al. 1997) and the western part of the Palaeotethys, through a northward dipping subduction underneath the accreted southern margin of Laurasia. This led to an oblique continent-continent collision along a dextral transcurrent suture zone (Stampfli et al. 2000). As a consequence, the Hun composite superterrane, sandwiched between the two supercontinents, was obliquely accreted to Laurasia, then internally sliced, duplicated and thickened by large-scale thrust and transcurrent fault tectonics, thus constituting the backbone of the European Variscan belt. According to Faure et al. (1997), the southward subduction of the Rheic ocean was responsible for major back-arc extension (e.g. Brévenne rift) within the internal Variscides during the Mid to Late Devonian (c. 380-360 Ma). The Early Carboniferous is characterised by compressional nappe tectonics, relayed by a transcurrent/extensional regime with ductile stretching and exhumation processes from Mid-Carboniferous to Permian times (Burg et al. 1994; Faure 1995). This extension period is characterised by very high thermal gradients. Exhumed rocks record $\mathrm{P}-\mathrm{T}-\mathrm{t}$ paths characterised by high-T (up to $700-800^{\circ} \mathrm{C}$ ),

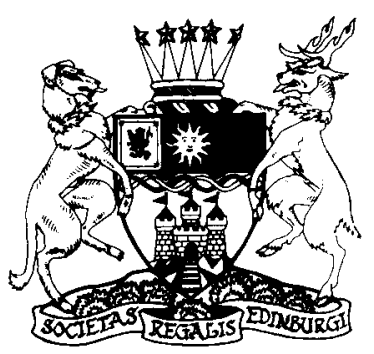

near isothermal, 9-4 kbar $(1 \mathrm{kbar}=100 \mathrm{Mpa})$ decompression before cooling, with T peak ages of $c .330-310 \mathrm{Ma}$ (Rey et al. 1997). Huge volumes of granitic magmas intruded mostly between $340 \mathrm{Ma}$ and $290 \mathrm{Ma}$, and represent, together with the migmatitic domes, about $80 \%$ of the internal zones of the belt. At the same time (c. $335 \mathrm{Ma}$ in the Vosges, e.g. Schaltegger et al. 1999; c. 310-290 Ma in the Pyrenees, Vielzeuf \& Pin 1989), the lower crust experienced a high-T-low $\mathbf{P}$ granulite facies metamorphism (e.g. Pin \& Vielzeuf 1983), and intrusion of mantle-derived mafic-ultramafic complexes.

The Variscan evolution outlined above is also documented in the Alps (Von Raumer \& Neubauer 1993; Von Raumer et al. 1999a). The most clearly exposed outcrops are located in the so-called External Crystalline Massifs of the French and Swiss Alps (i.e. from $\mathrm{S}$ to $\mathrm{N}$ : Argentera, Pelvoux, Belledonne-Grandes Rousses, Aiguilles Rouges-Mont Blanc (ARMB), Aar-Gotthard) (Fig. 1). The latter represent updomed basement nappes or slices appearing as Alpine antiform cores among their Mesozoic cover. As a consequence of the Alpine orogeny, the Tertiary tectono-metamorphic overprint of anchizonal to epizonal grade was often strong enough to generate new mineral parageneses, and, more importantly, to prevent the use of isotopic methods of dating which are sensitive to temperature and/or deformation, such as the $\mathrm{Rb}-\mathrm{Sr}, \mathrm{K}-\mathrm{Ar}$ or Ar-Ar techniques. Progress in our knowledge of the Variscides in the Alps was thus seriously hampered until high-precision, single-grain $\mathrm{U}-\mathrm{Pb}$ dating of accessory minerals (i.e. zircon, monazite, sphene, etc.) became available. This proved to be the most appropriate geochronological tool, as carefully selected zircon or monazite crystals survive perfectly isotopic resetting under high-T and/or high-P metamorphic conditions (see e.g. Bussy \& Cadoppi 1996; Bussy et al. 1998). The systematic dating of granitic intrusions within the Aar-Gotthard 


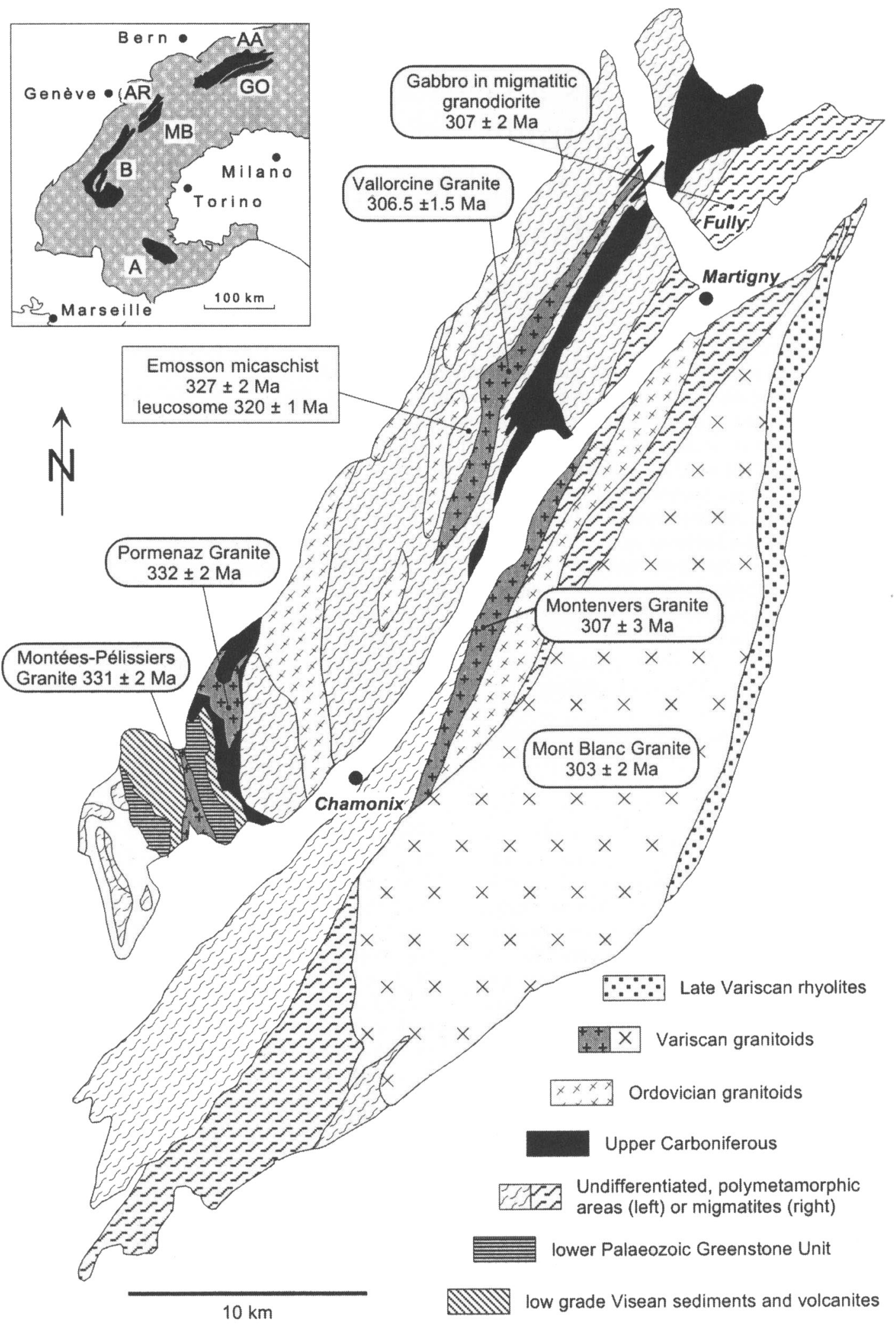

Figure 1 Simplified geological map of the Aiguilles Rouges-Mont Blanc massifs, after Von Raumer et al. (1999). Most of the NE-SW-trending lithological contacts are transcurrent tectonic features, which formed during the Late Variscan strike-slip regime and were reactivated during the Alpine orogeny. Insert: tectonic sketch map of the Western Alps (shaded) with location of the pre-Mesozoic External Crystalline Massifs (in black). AA: Aar; GO: Gotthard; AR: Aiguilles Rouges; MB: Mont Blanc; B: Belledonne; A: Argentera. 
(Schaltegger 1994; Schaltegger \& Corfu 1995; Schaltegger 1997) and AR-MB massifs (Bussy \& Von Raumer 1993; Bussy \& Hernandez 1997) showed that the magmatic activity in this part of the Variscides consisted of discrete short-lived pulses, whose typology is evolving through time.

This paper reports high-precision $\mathrm{U}-\mathrm{Pb}$ ages of the Late Carboniferous magmatic intrusions in the Aiguilles Rouges massif and discusses these new data in the framework of a geodynamic interpretation.

\section{Geological framework of the Aiguilles Rouges massif}

The Aiguilles Rouges massif (including its northern termination, known as the Fully massif) consists of a complex assemblage of tectonic units with contrasting maximum $\mathbf{P}-\mathrm{T}$ metamorphic conditions, separated by major, steeply dipping NE--SW faults and/or mylonitic zones (Fig. 1). Most of these tectonic contacts probably formed during the late Variscan strike-slip regime and were reactivated during the Alpine orogeny. The Aiguilles Rouges massif is essentially composed of polymetamorphic, amphibolite-facies grade rocks and granitic plutons. Low-grade monometamorphic detrital sediments with interlayered volcanites record an Early Carboniferous basin at the southern end of the massif (Dobmeier 1996), while unmetamorphosed continental, coal-bearing deposits of Late Carboniferous age (308-297 Ma, Capuzzo \& Bussy 1999) are mainly preserved in the Salvan-Dorénaz alpine syncline in the northern part of the massif.

Age determinations in the polymetamorphic units of the External Crystalline Massifs demonstrate a polyorogenic evolution, comprising not only Variscan, but also Ordovician and late Precambrian events (Von Raumer 1998; Von Raumer et al. 1999a). In the AR-MB area, magmatic ages on zircon of c. $450 \mathrm{Ma}$ have been obtained both for eclogitised MORB-like basic rocks (Paquette et al. 1989) and for S-type and I-type calc-alkaline non-eclogitised metagranites (Bussy \& Von Raumer 1993). The latter intruded detrital sequences (now paragneisses) of supposedly late Precambrian to Ordovician age, which might partly represent a former accretionary prism (Von Raumer 1998). This association has been interpreted as evidence for an Ordovician subduction zone, in either an island-arc, or an active continental margin environment, linked to the southward subduction of the Rheic oceanic lithosphere beneath Gondwana (Von Raumer et al. 1999b). The subsequent high-P event $\left(700^{\circ} \mathrm{C},>14 \mathrm{kbar}\right)$ recorded by eclogites is not precisely dated. Paragneisses display a succession of deformation events attributed to the Variscan continental collision, with thrust tectonics (Dobmeier 1998) and nappe stacking, leading to the development of a Barrowian type of metamorphism (Von Raumer et al. 1999a). Metapelites record a typical clockwise $\mathrm{P}-\mathrm{T}$ path (Fig. 2), as commonly found in the internal parts of the Variscides. Rocks of suitable composition experienced partial melting during the high-T decompression stage.

Magmatic rocks are widespread in the Aiguilles Rouges massif, as pre-Carboniferous medium- to high-grade metamorphosed rocks (e.g. Wirsing 1997; Paquette et al. 1989; Von Raumer et al. 1990; Dobmeier et al. 1999) or as Carboniferous, essentially non- to weakly metamorphosed intrusions. The latter include peraluminous granites hosting mafic enclaves, as well as a monzonitic intrusion (Fig. 1). Peraluminous rocks are also found in the nearby Mont Blanc massif, as well as a large syenogranitic pluton, which hosts mafic stocks, microgranular enclaves and synplutonic dykes (Bussy 1990). Subvolcanic facies are associated with some of

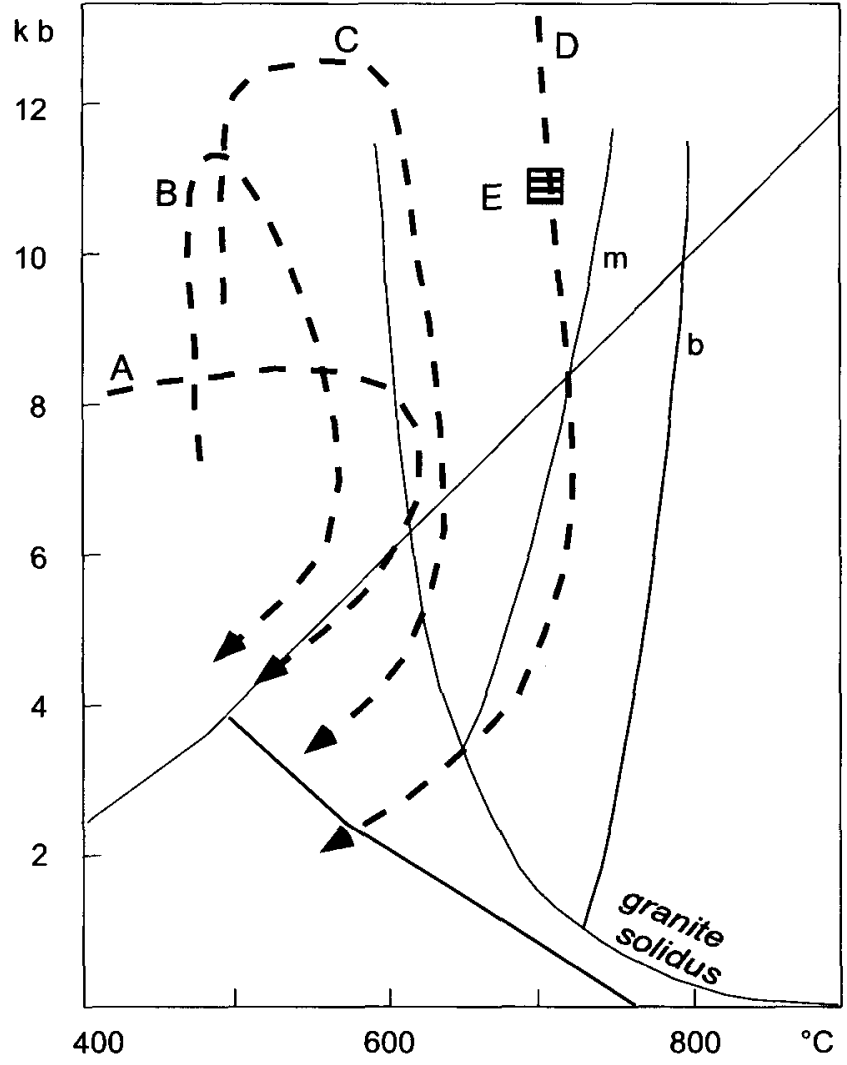

Figure 2 Variscan P-T evolution of the central part of the Aiguilles Rouges massif (Von Raumer et al. 1999a). A, B, C: garnet-bearing micaschists (for detailed sample description, sce Schulz \& Von Raumer 1993); D: retrograded eclogites; E: kyanite-bearing tonalitic melts spatially associated with $\mathrm{D}$. Reaction curves: Al-silicate stability fields after Holdaway (1971); solidus of granites and corresponding dehydration melting curves of muscovite $(\mathrm{m})$ and biotite (b) after Thompson (1990).

the intrusions, whereas volcanic horizons are interlayered in the Early (Dobmeier 1996) and Late Carboniferous (Capuzzo \& Bussy 1999) detrital basins, respectively.

\section{Granite characteristics and dating}

\subsection{U-Pb dating procedure}

Zircon and monazite have been dated using the conventional isotope dilution technique on single-grain or small multigrain fractions. The two minerals have been isolated using conventional heavy liquid and magnetic separation techniques. Air-abrasion was applied systematically to both zircon and monazite, to reduce or eliminate surface-correlated lead loss and younger overgrowths (Krogh 1982). Chemistry and measurements followed the standard procedure developed at the Royal Ontario Museum (Krogh 1973) and detailed e.g. in Bussy et al. (1995). When present, common $\mathrm{Pb}$ was subtracted according to the model of Stacey and Kramers (1975), using the calculated ${ }^{207} \mathrm{~Pb} /{ }^{206} \mathrm{~Pb}$ crystallisation ages. Regression lines were computed using the ISOPLOT/EX program of Ludwig (1999). All errors are quoted at the $95 \%$ confidence level.

The selection of zircon crystals free of older inherited cores is a crucial, but difficult task, when using the isotope dilution approach, as opposed to the in-situ ion probe technique. This is particularly critical when handling peraluminous, crustalderived magmatic rocks, as more than $95 \%$ of their zircons do host an inherited core. A successful approach consists in selecting zircon crystals showing a central, tubular void or 
Table 1 Main petrological characteristics of the dated plutons.

\begin{tabular}{|c|c|c|c|c|c|c|}
\hline & Pormenaz & $\begin{array}{l}\text { Montées- } \\
\text { Pélissier }\end{array}$ & Vallorcine & granitoids & enclaves & Mont Blanc \\
\hline Rock types & $\begin{array}{l}(\mathrm{qtz}) \mathrm{mzt} \\
(\mathrm{qtz}) \mathrm{mzd} \\
(\mathrm{grd}, \mathrm{mzgt})\end{array}$ & $\begin{array}{l}\text { mzgt, grd, } \\
\text { lamprophyres - }\end{array}$ & $\begin{array}{l}\text { mzgt, grd, } \\
\text { aplite, } \\
\text { lamprophyres - }\end{array}$ & $\begin{array}{l}\text { migmatites, } \\
\text { grd, qtz-drt } \\
\text { (leuco)grt }\end{array}$ & $\begin{array}{l}\text { (qtz)gabbro } \\
\text { qtz-diorite }\end{array}$ & $\begin{array}{l}\text { sygt, mzgt, leucogrt } \\
\text { grd (enclaves) } \\
\text { mzd (stocks \& } \\
\text { synplut.dykes }\end{array}$ \\
\hline Enclaves & durbachites & $\begin{array}{l}\text { restites - } \\
\text { MME - }\end{array}$ & $\begin{array}{l}\text { restites + } \\
\text { MME }\end{array}$ & $\begin{array}{l}\text { restites ++ } \\
\mathrm{MME}+, \text { gab }\end{array}$ & & $\mathrm{MME}++$ \\
\hline $\begin{array}{l}\text { Rock-forming } \\
\text { mineralogy }\end{array}$ & $\begin{array}{l}\text { kf, plg, qtz, } \\
\text { Mg-hbl, bi, } \\
\text { spn(up to } 3-5 \% \text { ) }\end{array}$ & $\begin{array}{l}\mathrm{plg}, \mathrm{kf}, \mathrm{qtz}, \\
\mathrm{mu}, \mathrm{bi},\end{array}$ & $\begin{array}{l}\text { plg, kf, qtz, } \\
\text { bi, mu, }\end{array}$ & $\mathrm{bi}, \mathrm{mu}, \mathrm{crd}$ & $\begin{array}{l}\text { plg, hbl, } \\
\text { bi, kf, qtz }\end{array}$ & $\begin{array}{l}\text { plg, kf, qtz, } \\
\text { bi, hbl }\end{array}$ \\
\hline $\begin{array}{l}\text { Accessory } \\
\text { mineralogy }\end{array}$ & $\begin{array}{l}\text { ap, zr, chl, py, } \\
\text { ilm, mgt, rt, mon, }\end{array}$ & $\begin{array}{l}\text { ap, zr, spn, } \\
\text { mon, rt, ilm }\end{array}$ & $\begin{array}{l}\text { ap, zr, and, top, } \\
\text { crd, tm, grt, spn, } \\
\text { mon, rt, hem, py }\end{array}$ & $\begin{array}{l}\text { ap, zr, grt, } \\
\text { spn, mon, } \\
\text { tm, ilm }\end{array}$ & $\begin{array}{l}\text { spn, ap, zr, } \\
\text { p, ep, mu, } \\
\text { chl, }\end{array}$ & $\begin{array}{l}\text { aln, spn, ap, zr, } \\
\text { ilm, tho, mol, }\end{array}$ \\
\hline \multicolumn{7}{|l|}{ Chemistry } \\
\hline $\mathrm{SiO}_{2}(\mathrm{wt}-\%)$ & $44-75$ & $67-68$ & $66-76$ & $57-75$ & $46-53$ & $55-77$ \\
\hline $\mathrm{K}_{2} \mathrm{O}$ & $3 \cdot 4-6 \cdot 1$ & $5 \cdot 3 \cdot 6 \cdot 3$ & $2 \cdot 7-5 \cdot 9$ & $1 \cdot 3-5 \cdot 8$ & $1 \cdot 9-3 \cdot 5$ & $2 \cdot 5-6 \cdot 0$ \\
\hline $\mathrm{K}_{2} \mathrm{O} / \mathrm{Na}_{2} \mathrm{O}$ & $1 \cdot 0-3 \cdot 1$ & $1 \cdot 9-3 \cdot 0$ & $0 \cdot 6-2 \cdot 1$ & $0 \cdot 3-2 \cdot 1$ & $1 \cdot 3-3 \cdot 3$ & $0 \cdot 8-1 \cdot 7$ \\
\hline ASI & $\begin{array}{l}\text { metalum (mzt) } \\
\text { peralum (mzgt) }\end{array}$ & peralum & peralum & peralum & metalum & $\begin{array}{l}\text { metalum to } \\
\text { peralum }\end{array}$ \\
\hline $\mathrm{MgO} / \mathrm{FeO}^{*}$ & $0.5-1.6$ & $0 \cdot 3-0 \cdot 8$ & $0 \cdot 1-0.6$ & $0 \cdot 2-0 \cdot 7$ & $0 \cdot 8-1 \cdot 8$ & 0.040 .9 \\
\hline $\mathrm{Rb}(\mathrm{ppm})$ & $140-275$ & $230-270$ & $123-335$ & $50-340$ & $90-175$ & $170-490$ \\
\hline $\mathrm{Ba}$ & $985-6365$ & $1130-1570$ & $22-790$ & $160-960$ & $360-1300$ & $10-800$ \\
\hline Th & $<3-55$ & $20-40$ & $<3-25$ & $<3-17$ & $2-5$ & $<3-50$ \\
\hline $\mathrm{Zr}$ & $20-590$ & $150-175$ & $15-225$ & $40-260$ & $70-135$ & $40-400$ \\
\hline $\mathrm{Y}$ & $5-40$ & $12-14$ & $6-32$ & $<5-45$ & $11-33$ & $30-70$ \\
\hline $\mathrm{La}$ & $<5-130$ & $16-38$ & $4-38$ & $<5-31$ & $13-20$ & $20-54$ \\
\hline$(\mathrm{La} / \mathrm{Yb})_{N}[\mathrm{n}]$ & $16 \cdot 2-28 \cdot 4[2]$ & $17 \cdot 9-21 \cdot 4[3]$ & $4 \cdot 5-16 \cdot 1[8]$ & $5 \cdot 1-7 \cdot 7[2]$ & $3 \cdot 6-4 \cdot 9[4]$ & $1 \cdot 6-10 \cdot 6[9]$ \\
\hline $\mathrm{Eu} / \mathrm{Eu}^{*}$ & $0.67-0.75$ & $0.74-0.82$ & $0.43-0.56$ & $0.45-0.73$ & $0 \cdot 85-1 \cdot 05$ & $0.08-0.52$ \\
\hline Granite type & $\mathrm{Mg}-\mathrm{K}$ & Al-K & $\mathrm{Al}-\mathrm{K}$ & $\mathrm{Al}-\mathrm{K}$ & & $\mathrm{Fe}-\mathrm{K}$ \\
\hline Age (Ma) & $332 \pm 2$ & $331 \pm 2$ & $306.5 \pm 1.5$ & $307 \pm 2$ & $307 \pm 2$ & $303 \pm 2$ \\
\hline References & 1,2 & $I$ & 3 & 4,5 & 5 & 6 \\
\hline
\end{tabular}

aln: allanite; and: andalusite; ap: apatite; ASI: aluminum saturation index; bi: biotite; chl: chlorite; crd: cordicrite; ep: epidote; grd: granodiorite; grt: garnet; hem: hematite; hbl: hornblende; ilm: ilmenite; kf: K-feldspar; mgt: magnetite; MME: mafic microgranular enclave; mol: molybdenite; mon: monazite; mu: muscovite; mzd: monzodiorite; mzt: monzonite; mzgt: monzogranite; [n]: number of analyses; op: opaque minerals; plg: plagioclase; py: pyrite; qtz: quartz; rt: rutile; spn: sphene; sygt: syenogranite; tho: thorite; tm: tourmaline; top: topaze; zr: zircon; ++: very abundant, +: abundant, -: rare. Empty field = no available data. References: 1: Dobmeier (1996); 2: Délitroz and Fellay (1997); 3: Brändlein (1991) and Brändlcin et al. (1994); 4: Krummenacher (1959); 5: Bovay (1988); 6: Bussy (1990).

melt inclusion (see e.g. fig. 6a in Bussy \& Cadoppi 1996), or very thin needle-like zircon prisms, unlikely to host isometric cores.

\subsection{The Aiguilles Rouges metapelites and migmatites}

Paragneisses of the Aiguilles Rouges massif are particularly well exposed in the Lake Emosson-Val Berard area (Von Raumer \& Schwander 1985; Schulz \& Von Raumer 1993). Their main foliation has a $\mathrm{N}-\mathrm{S}$ subvertical orientation, parallel to the major structures of the massif. Progressive deformation first produced high-T microstructures and isoclinal folds characteristic of deep crustal levels. Subsequent deformation occurred when the rocks were at increasingly higher and colder levels, to end with subvertical low-T mylonitic foliation and $\mathrm{C}-\mathrm{S}$ structures. Steeply plunging axes of kilometre-scale ductile folds affecting migmatite leucosomes, as well as the geometry of the low-T structures document a long-lasting and marked transcurrent dextral shearing along the subvertical foliation planes (Schulz \& Von Raumer 1993).

Metapelites display amphibolite-grade mineral assemblages consisting of biotite + oligoclase + quartz + sillimanite \pm garnet \pm cordierite \pm muscovite \pm K-feldspar. Relics of staurolite and kyanite record an earlier higher-pressure event. Calculated peak temperatures are up to $650^{\circ} \mathrm{C}$ (Schulz \& Von Raumer 1993). The Aiguilles Rouges metapelites are rich in small, euhedral, crystals of colourless to pale-yellowish monazite. Three single-grain fractions (EMIC [31-33], Tab. 2) selected from a micaschist sample from the Emosson lake shore (Fig. 1) yielded a mean concordant $\mathrm{U}-\mathrm{Pb}$ age of $327 \pm 2 \mathrm{Ma}$ (Fig. 5H). The good reproducibility and concordancy of the data allow us to consider this age as geologically meaningful, in the absence of crystal rejuvenation features (Vavra \& Schaltegger 1999). Considering the fact that monazite crystallised as inclusions in minerals of the high-T metamorphic stage, and below the blocking temperature of the $\mathrm{U}-\mathrm{Pb}$ isotopic system set at $780^{\circ} \mathrm{C}$ (Dahl 1997), we interpret this age as the time of peak temperature conditions for the amphibolitefacies metamorphism of the Aiguilles Rouges metapelites.

Partial melting affected most lithologies in the Aiguilles Rouges massif, i.e. Ordovician orthogneisses, metapelites and metagraywackes. Migmatites are heterogeneously distributed, which is ascribed to the tectonic juxtaposition of slices with contrasting maximum metamorphic conditions, as well as to variable water content and mineralogical composition. The typical mineral assemblage of the leucosomes is: K-feldspar + oligoclase + quartz \pm biotite \pm sillimanite \pm muscovite \pm cordierite. Maximum calculated temperatures are in the range 650-700 ${ }^{\circ} \mathrm{C}$ (Fig. 2) (Schultz \& Von Raumer 1993; Von Raumer et al. 1996).

Migmatitic metagraywackes are in tectonic contact with the EMIC metapelites at Lake Emosson. Leucosomes occur as evenly spaced, foliation parallel, millimetre-thick ribbons. intensely deformed and folded with steeply plunging axes correlated to a dextral transcurrent shearing. Leucocratic dykelets $10-30 \mathrm{~cm}$ wide cut across the migmatites, locally organised in dextral en échelon structures. The migmatites consist of quartz, perthitic K-feldspar, oligoclase (An25), biotite (cationic $\mathrm{Fe} / \mathrm{Mg}: 1.85$ ), muscovite, with apatite and zircon concentrated in the biotite-rich melanosomes, Monazite is found as euhedral overgrowth on apatite and zircon. Discordant dykelets almost 
Table $2 \mathrm{U}-\mathrm{Pb}$ isotopic data on zircon and monazite extracted from the investigated samples.

\begin{tabular}{|c|c|c|c|c|c|c|c|c|c|c|c|c|}
\hline \multirow{3}{*}{$\begin{array}{l}\text { Sample } \\
\text { (fraction [\#] } \\
\& \text { characteristics) }\end{array}$} & \multirow{3}{*}{$\begin{array}{l}\text { Mass } \\
\text { mg }\end{array}$} & \multicolumn{2}{|c|}{ Conc. } & \multirow{3}{*}{$\begin{array}{c}{ }^{208} \mathrm{~Pb}^{*} \\
\mathrm{a}\end{array}$} & \multicolumn{5}{|c|}{ Atomic ratios } & \multicolumn{3}{|c|}{ Apparent ages (Ma) } \\
\hline & & $\mathrm{U}$ & $\mathrm{Pb}^{*}$ & & $\mathrm{Th} / \mathrm{U}$ & $206 / 204$ & $206 / 238$ & $207 / 235$ & $207 / 206$ & $6 / 38$ & $7 / 35$ & $7 / 6$ \\
\hline & & \multicolumn{2}{|c|}{ ppm } & & & & & & & & & \\
\hline \multicolumn{13}{|c|}{ PORM Pormenaz monzonite (FB975) } \\
\hline [1] single pr & 0.006 & 289 & 17 & 17 & $0 \cdot 67$ & 5331 & $0 \cdot 05288 \pm 26$ & $0 \cdot 3871 \pm 22$ & $0.05309 \pm 12$ & $332 \cdot 2$ & $332 \cdot 2$ & $332 \cdot 7$ \\
\hline [2] 2 cless pr & 0.004 & 409 & 24 & 18 & 0.71 & 5185 & $0 \cdot 05284 \pm 26$ & $0 \cdot 3863 \pm 22$ & $0.05302 \pm 14$ & 331.9 & 331.6 & $329 \cdot 6$ \\
\hline [3] 3 small pr & 0.003 & 207 & 12 & 10 & 0.36 & +473 & $0 \cdot 05280 \pm 26$ & $0 \cdot 3865 \pm 40$ & $0.05309 \pm 44$ & $331 \cdot 7$ & $331 \cdot 8$ & $332 \cdot 8$ \\
\hline \multicolumn{13}{|c|}{ MPEL Montées-Pélissier granite (FB974) } \\
\hline [4] 3 small ndl & 0.002 & 464 & 27 & 17 & 0.68 & 2692 & $0 \cdot 05246 \pm 26$ & $0 \cdot 3836 \pm 26$ & $0 \cdot 05304 \pm 24$ & $329 \cdot 6$ & $329 \cdot 7$ & $330 \cdot 5$ \\
\hline [5] 3 small ndl & 0.002 & 484 & 28 & 18 & 0.71 & 1693 & $0 \cdot 05328 \pm 26$ & $0 \cdot 3911 \pm 28$ & $0.05325 \pm 26$ & $334 \cdot 6$ & $335 \cdot 2$ & $339 \cdot 4$ \\
\hline [6] $3 \mathrm{hlw}$ ndl & 0.002 & 582 & 32 & 13 & 0.51 & 4804 & $0 \cdot 05276 \pm 26$ & $0 \cdot 3858 \pm 24$ & $0.05303 \pm 18$ & $331 \cdot 4$ & $331 \cdot 3$ & $330 \cdot 2$ \\
\hline [7] single pr & 0.002 & 587 & 30 & 11 & $0 \cdot 42$ & 2547 & $0 \cdot 05052 \pm 38$ & $0 \cdot 3701 \pm 26$ & $0 \cdot 05313 \pm 22$ & $317 \cdot 7$ & $319 \cdot 7$ & $334 \cdot 2$ \\
\hline \multicolumn{13}{|c|}{ VALG Vallorcine granite (VAL4) } \\
\hline [8] $15 \mathrm{pr}$ & 0.008 & 470 & 27 & 6 & $0 \cdot 19$ & 8291 & $0.06019 \pm 28$ & $0 \cdot 4548 \pm 24$ & $0.05480 \pm 9$ & $376 \cdot 8$ & $380 \cdot 6$ & $404 \cdot 0$ \\
\hline [9] $30 \mathrm{pr}$ & 0.042 & 356 & 24 & 6 & $0 \cdot 12$ & 27990 & $0 \cdot 07044 \pm 34$ & $0.6058 \pm 33$ & $0 \cdot 06238 \pm 9$ & $438 \cdot 8$ & $480 \cdot 9$ & $687 \cdot 0$ \\
\hline [10] $21 \mathrm{pr}$ tips & $0 \cdot 018$ & 493 & 30 & 8 & $0 \cdot 18$ & 8905 & $0.06103 \pm 29$ & $0 \cdot 5055 \pm 28$ & $0 \cdot 06008 \pm 9$ & 381.9 & $415 \cdot 4$ & $606 \cdot 3$ \\
\hline [11] $38 \mathrm{ndl}$ & $0 \cdot 027$ & 631 & 33 & 5 & $0 \cdot 16$ & +8638 & $0.05423 \pm 26$ & $0 \cdot 4030 \pm 22$ & $0 \cdot 05390 \pm 10$ & $340 \cdot 4$ & $343 \cdot 9$ & $367 \cdot 0$ \\
\hline$[12] 20 \mathrm{pr}$ & 0.032 & 645 & 39 & 4 & 0.13 & 71614 & $0.06333 \pm 30$ & $0.4924 \pm 26$ & $0.05640 \pm 9$ & $395 \cdot 8$ & $406 \cdot 6$ & $468 \cdot 1$ \\
\hline [13] $21 \mathrm{pr}$ tips & $0 \cdot 128$ & 258 & 21 & 21 & 1.33 & 25626 & $0.07024 \pm 33$ & $0-6729 \pm 36$ & $0.06948 \pm 11$ & $437 \cdot 6$ & $522 \cdot 5$ & $913 \cdot 1$ \\
\hline [14] $3 \mathrm{hlw} \mathrm{pr}$ & 0.001 & 1902 & 85 & 5 & $0 \cdot 14$ & 2492 & $0.04721 \pm 22$ & $0 \cdot 3412 \pm 19$ & $0.05242 \pm 10$ & $297 \cdot 4$ & $298 \cdot 1$ & $303 \cdot 9$ \\
\hline [15] $4 \mathrm{hlw} \mathrm{pr}$ & 0.002 & 1490 & 69 & 5 & $0-12$ & 3253 & $0.04866 \pm 23$ & $0 \cdot 3530 \pm 20$ & $0 \cdot 05262 \pm 10$ & $306 \cdot 3$ & $307 \cdot 0$ & $312 \cdot 4$ \\
\hline [16] 3 pr chips & 0.003 & 550 & 38 & 10 & 0.33 & 3287 & $0.06859 \pm 32$ & $0.5506 \pm 30$ & $0.05822 \pm 11$ & $427 \cdot 7$ & $445 \cdot 4$ & $538 \cdot 1$ \\
\hline [17] $6 \mathrm{hlw} \mathrm{pr}$ & 0.004 & 983 & 46 & 7 & $0 \cdot 22$ & 4768 & $0.04854 \pm 22$ & $0 \cdot 3517 \pm 19$ & $0.05255 \pm 10$ & $305 \cdot 6$ & $306 \cdot 0$ & $309 \cdot 6$ \\
\hline [18] 3 mon & $0-001$ & 7524 & 1165 & 71 & $8 \cdot 09$ & 8078 & $0.04866 \pm 12$ & $0 \cdot 3524 \pm 10$ & $0.0525 \pm 16$ & $306 \cdot 3$ & $306 \cdot 5$ & 307.9 \\
\hline [19] 3 mon & 0.001 & 7914 & 1095 & 68 & $6 \cdot 87$ & 9303 & $0.04861 \pm 12$ & $0 \cdot 3519 \pm 10$ & $0.05250 \pm 4$ & $306 \cdot 0$ & $306 \cdot 1$ & $307 \cdot 4$ \\
\hline \multicolumn{13}{|c|}{ FGAB - Fully Gabbro (FB1034) } \\
\hline [20] 13 small pr & $0 \cdot 004$ & 431 & 22 & 14 & $0 \cdot 51$ & 4125 & $0.04882 \pm 24$ & $0 \cdot 3534 \pm 20$ & $0.05250 \pm 14$ & $307 \cdot 3$ & $307 \cdot 3$ & $307 \cdot 2$ \\
\hline [21] $2 \mathrm{pr}$ & $0 \cdot 004$ & 481 & 25 & 13 & $0-50$ & 4839 & $0 \cdot 04870 \pm 22$ & $0 \cdot 3525 \pm 20$ & $0 \cdot 05249 \pm 14$ & $306 \cdot 6$ & $306 \cdot 6$ & $306 \cdot 7$ \\
\hline \multicolumn{13}{|c|}{ FLEC Fully leucogranite (FB1035) } \\
\hline [22] $3 \mathrm{hlw}$ pr & 0.003 & 414 & 19 & 11 & 0.41 & 2957 & $0.04391 \pm 20$ & $0 \cdot 3180 \pm 20$ & $0.05252 \pm 18$ & $277 \cdot 0$ & $280 \cdot 4$ & $308 \cdot 2$ \\
\hline [23] single hlw pr & $0 \cdot 004$ & 153 & 9 & 23 & 0.97 & 2146 & $0.04869 \pm 26$ & $0 \cdot 3524 \pm 28$ & $0.05249 \pm 28$ & $306 \cdot 5$ & $306 \cdot 5$ & $306 \cdot 6$ \\
\hline [24] hlw pr chip & $0-002$ & 167 & 10 & 24 & $1 \cdot 00$ & 985 & $0.04844 \pm 26$ & $0 \cdot 3506 \pm 42$ & $0.05248 \pm 52$ & $305 \cdot 0$ & $305 \cdot 1$ & $306 \cdot 5$ \\
\hline \multicolumn{13}{|c|}{ FGRD Fully anatectic granodiorite (FB1036) } \\
\hline [25] single hlw pr & 0.005 & 154 & 14 & 8 & 0.28 & 3592 & $0.08873 \pm 44$ & $0 \cdot 7463 \pm 44$ & $0 \cdot 06101 \pm 18$ & $548 \cdot 0$ & $566 \cdot 1$ & $639 \cdot 5$ \\
\hline [26] 2 acic pr & 0.002 & 74 & 4 & 11 & 0.39 & 551 & $0.04882 \pm 36$ & $0 \cdot 3528 \pm 88$ & $0.05241 \pm 120$ & $307 \cdot 3$ & $306 \cdot 8$ & $303 \cdot 4$ \\
\hline [27] 2 tiny ndl & 0.001 & 259 & 12 & 8 & 0.29 & 712 & $0 \cdot 04794 \pm 28$ & $0 \cdot 3468 \pm 46$ & $0.05247 \pm 60$ & 301.9 & $302 \cdot 3$ & $305 \cdot 8$ \\
\hline [28] $2 \mathrm{pr}$ & 0.001 & 160 & 7 & 6 & $0 \cdot 21$ & 249 & $0.04532 \pm 32$ & $0 \cdot 3288 \pm 116$ & $0.052611 \pm 74$ & $285 \cdot 7$ & $288 \cdot 6$ & $312 \cdot 1$ \\
\hline [29] single mon & 0.002 & 6291 & 599 & 53 & 3.71 & +7997 & $0 \cdot 04878 \pm 24$ & $0.3531 \pm 20$ & $0.0524 \pm 98$ & $307 \cdot 0$ & $307 \cdot 0$ & $306 \cdot 9$ \\
\hline [30] single mon & 0.002 & 3770 & 360 & 53 & $3 \cdot 72$ & +8324 & $0 \cdot 04890 \pm 24$ & $0 \cdot 3540 \pm 20$ & $0.05250 \pm 10$ & $307 \cdot 8$ & $307 \cdot 7$ & $307 \cdot 3$ \\
\hline \multicolumn{13}{|c|}{ EMIC - Emosson micaschist (FB1023) } \\
\hline [31] single mon & 0.001 & 8644 & 1193 & 66 & $6 \cdot 18$ & 4655 & $0.05216 \pm 26$ & $0 \cdot 3812 \pm 22$ & $0 \cdot 05300 \pm 14$ & $327 \cdot 8$ & $327 \cdot 9$ & $328 \cdot 7$ \\
\hline [32] single mon & 0.001 & 6954 & 789 & 58 & $4 \cdot 55$ & 3843 & $0.05195 \pm 26$ & $0 \cdot 3793 \pm 22$ & $0 \cdot 05295 \pm 14$ & $326 \cdot 5$ & $326 \cdot 5$ & $326 \cdot 8$ \\
\hline [33] single mon & 0.002 & 2981 & 239 & 41 & $2 \cdot 26$ & 5889 & $0 \cdot 05196 \pm 26$ & $0 \cdot 3796 \pm 22$ & $0.05299 \pm 12$ & $326 \cdot 5$ & $326 \cdot 8$ & $328 \cdot 3$ \\
\hline \multicolumn{13}{|c|}{ ELEU - Emosson leucosome (FB1028) } \\
\hline [34] single mon & 0.001 & 4164 & 434 & 55 & $4 \cdot 14$ & 7264 & $0.05107 \pm 24$ & $0 \cdot 3709 \pm 20$ & $0 \cdot 05267 \pm 10$ & $321 \cdot 1$ & $320 \cdot 3$ & $314 \cdot 4$ \\
\hline [35] single mon & 0.001 & 5049 & 798 & 70 & $8 \cdot 14$ & 9590 & $0 \cdot 05125 \pm 24$ & $0 \cdot 3709 \pm 20$ & $0 \cdot 05250 \pm 10$ & $322 \cdot 2$ & $320 \cdot 3$ & $307 \cdot 0$ \\
\hline [36] 2 small mon & 0.001 & 8588 & 874 & 54 & $4 \cdot 01$ & 14150 & $0 \cdot 05104 \pm 26$ & $0 \cdot 3700 \pm 20$ & $0.05257 \pm 8$ & $320 \cdot 9$ & $319 \cdot 7$ & $310 \cdot 5$ \\
\hline
\end{tabular}

acic: acicular; cless: colourless; hlw: hollow; mon: monazite; ndl: needle; pr: prism; *: radiogenic; $\mathbf{a}$ : in mole- $\%$ relative to total radiogenic $\mathrm{Pb}$; $\mathbf{b}$ : calculated on the basis of ${ }^{208} \mathrm{~Pb} /{ }^{206} \mathrm{~Pb}$ ratios, assuming concordancy; $\mathrm{c}$; corrected for spike $\mathrm{Pb}$ and for fractionation; $\mathbf{d}$ : corrected for fractionation, spike, $\mathrm{U}$ and $\mathrm{Pb}$ blanks, and initial common $\mathrm{Pb}$ (Stacey \& Kramers 1975) when present $(+)$, error estimates $(95 \%$ confidence level) refer to the last significant digits of the isotopic ratios and reflect reproducibility of standards, measurement errors and uncertainties in the common $\mathrm{Pb}$ correction.

lack restitic material, but contain small euhedral Fe-Mn-rich garnets (Alm65, Sps25).

Two single-grain and one double-grain fractions ([34-36], Tab. 2) have been selected from a discordant leucosome dykelet (sample ELEU). They yielded identical dates within errors, although plotting slightly above the Concordia, a common feature in monazites (excess ${ }^{206} \mathrm{~Pb}$ ) (Fig. 5I). Relying preferentially on ${ }^{207} \mathrm{~Pb} /{ }^{235} \mathrm{U}$ data (Schärer 1984), a mean age of $320 \pm 1 \mathrm{Ma}$ is proposed for the magmatic crystallisation of the leucosome.

\subsection{The Fully gabbro-migmatite intrusion}

In the Fully vineyards, at the northern end of the Aiguilles Rouges massif, a highly heterogeneous intrusion of migmatitic aspect is observed over a distance of $7 \mathrm{~km}$ (Krummenacher 1959) (Fig. 1 and Tab. 1). The latter is a coarse-grained granodiorite with cordierite clots (up to $10 \mathrm{vol} \%$ ) (now greenish pinite), dispersed K-feldspar megacrysts and numerous small biotite-rich restitic enclaves. Schlieren and nebulitic structures are common. Micaschists, gneisses, marbles and amphibolites are found as decimetre-long xenoliths, whereas mafic magmatic enclaves can reach one metre in diameter. Cordierite-bearing leucogranitic dykes and stocks crosscut the main facies. No systematic internal structure is observed.

Although migmatitic structures are locally well preserved, the whole mass has a clear intrusive character. It is a typical peraluminous, anatectic granitoid with a large restitic component 


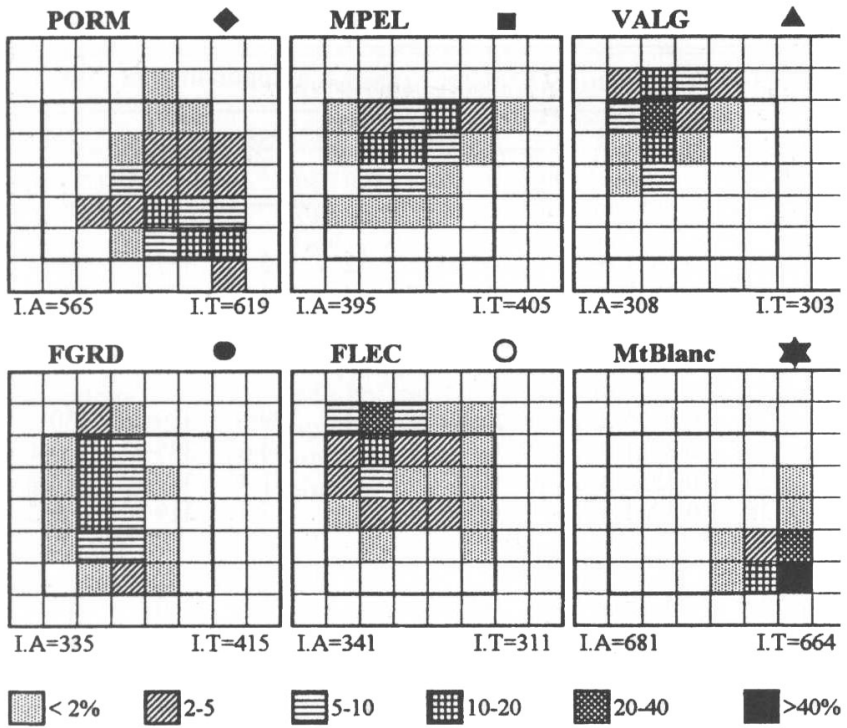

Figure 3 Zircon morphological distribution of the dated granitic intrusions according to Pupin (1980). Labels as in Table 2.

and abundant Al-rich minerals (cordierite, muscovite, hercynite). Zircons preferentially develop the $\{211\}$ crystallographic form (low $A$ index) (Fig. 3) and plot in the expected field of intrusive aluminous granites in the typological grid of Pupin (1988) (Fig. 4). Zircons with high T indices are unusually frequent within the granodiorite facies, a feature correlated to the proportion of mafic enclaves in the granite (Pupin 1980). The late leucogranitic dykes are clearly linked to the main anatectic mass, through differentiation by restite unmixing and/or fractional crystallisation processes.

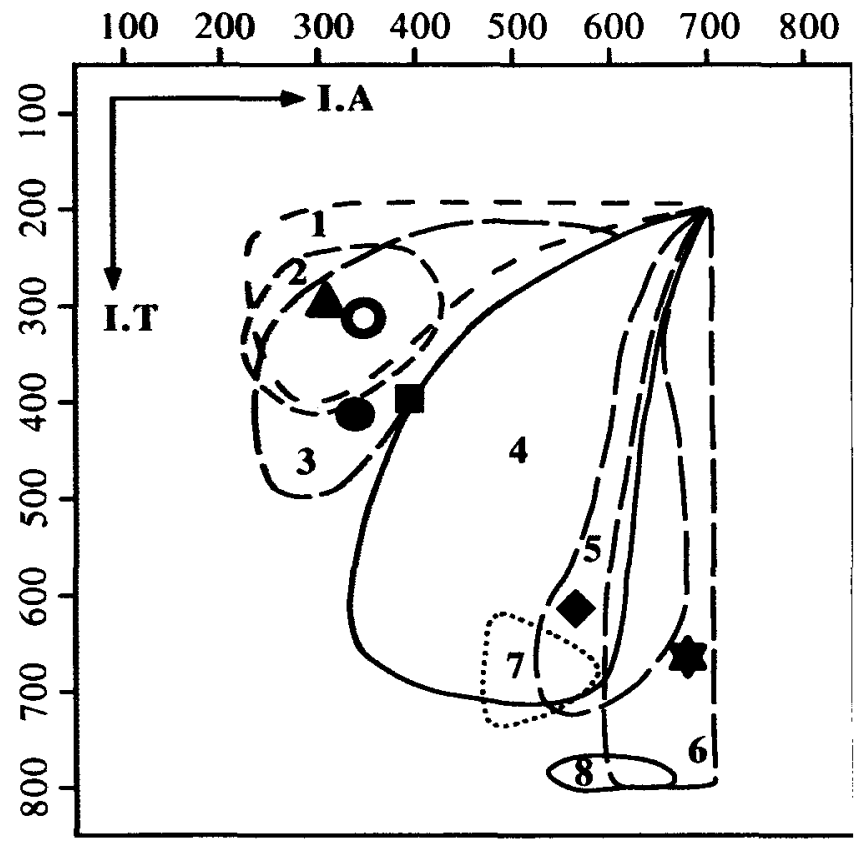

Figure 4 Mean zircon morphology $\mathrm{A} / \mathrm{T}$ points in the granite classification grid of Pupin (1988). $1=$ aluminous granites; $2=$ (sub)autochthonous monzogranites-granodiorites; $3=$ intrusive aluminous monzogranites-granodiorites; $4=$ calc-alkaline and $\mathrm{K}$ calc-alkaline series granites; $5=$ subalkaline series granites; $6=$ alkaline series granites; $7=$ continental tholeiitic granites; $8=$ oceanic tholeiitic series granites. Symbols as in Figure 3.
The mafic magmatic enclaves include typical mafic microgranular enclaves of intermediate composition (quartz-dioritic to granodioritic), as well as angular to rounded pieces of fine- to coarse-grained gabbros, up to one metre in size (Bovay 1988). The latter preserve clear, locally pegmatitic, undeformed igneous textures, but experienced hydrothermal alteration. Pyroxene recrystallised into $\mathrm{Mg}$-hornblende + minor $\mathrm{Mg}$ biotite and plagioclase (An60) is strongly sericitised. The angular shape and absence of chilled margins indicate that these gabbro enclaves are pieces of a larger mafic body, that were incorporated as solid-state fragments into the mobile migmatitic mass. They have chemical characteristics of calcalkaline type similar to those found in other Variscan acid-basic associations (e.g. Corsica, Pyrenees). Interactions with crustal material, possibly during hydrothermal retrogression, are evidenced by high contents in LILE like $\mathrm{K}$, Ba and $\mathrm{Rb}$ (Tab. 1). Zircon is found as large subhedral grains in pegmatitic facies. Simple facets, oscillatory zoning in BSE imaging, as well as central tubular melt inclusions, all evidence growth in a magmatic rather than solid-state context.

Zircon and monazite have been extracted from granodioritic (FGRD), leucogranitic (FLEC) and gabbro (FGAB) samples (Tab. 2). Two zircon fractions from FGAB [20-21] yielded perfectly concordant and identical ages of $307 \pm 2$ Ma (Fig. $5 \mathrm{E}$ ), interpreted as the crystallisation time of the gabbro enclaves. Hollow zircons were selected from FGRD and yielded a concordant age at $307 \mathrm{Ma}$ for [26], whereas [27] and [28] record a slight lead loss (Fig. 5G). On the other hand, prism [25] (not shown in Fig. 5G) is clearly inherited with a Pan-African age around $640 \mathrm{Ma}$. Two perfectly concordant monazite fractions [29-30] confirm the $307 \pm 2 \mathrm{Ma}$ age, interpreted as the crystallisation time of the anatectic granodiorite. Finally, three zircon fractions from FLEC [22-24] again yield the same age (Fig. 5F). These data indicate that, although solid at time of incorporation into the anatectic mass, the gabbro enclaves are contemporaneous with the acid magmatism within errors. In other words, mantle basic magmatism was active at a time of enhanced crustal anatexis.

\subsection{The Vallorcine granite}

Located in the northern part of the Aiguilles Rouges massif, the Vallorcine granite is a $15 \mathrm{~km}$-long by $1 \mathrm{~km}$ thick, sheet-like pluton (Fig. 1), which intruded along a steeply dipping, NESW trending, dextral strike-slip shear zone (Brändlein et al. 1994). Syntectonic intrusion is inferred on the basis of structural analysis, which documents long-lasting strike-slip shearing both in the country rocks (pre- and post-intrusion fabrics) and in the granite. The latter developed an early NE-SW trending magmatic flow structure, evolving locally into a postsolidus foliation. The Vallorcine granite was subsequently affected along its SE contact by an intense low-T ductile shearing leading to the well-known 'Miéville ultramylonite' (Kerrich et al. 1980) of Late Variscan age (but reworked during the Alpine orogeny). Alpine relief provides a $2000 \mathrm{~m}$-high natural cross-section through the pluton. The lowermost facies is a biotite-rich monzogranite (Tab. 1) hosting numerous enclaves up to $30 \mathrm{~cm}$ in size, including gneiss xenoliths from the country rocks, hornfelses, micaceous restites with sillimanite and hercynite, early cordierite-bearing leucogranite blocks and mafic microgranular enclaves. The upper facies is finer-grained with less biotite and almost no enclaves, pointing to an enclave unmixing process during upward motion of the magma. Aplitic and subvolcanic dykes are concentrated within the wall rocks of the upper contact. The Vallorcine intrusion is a typical S-type granite, as confirmed by zircon typology (Figs 3 and 4), stable isotopes (Brändlein et al. 1994) and the presence of Alrich minerals (cordierite, muscovite, andalusite, etc.). 

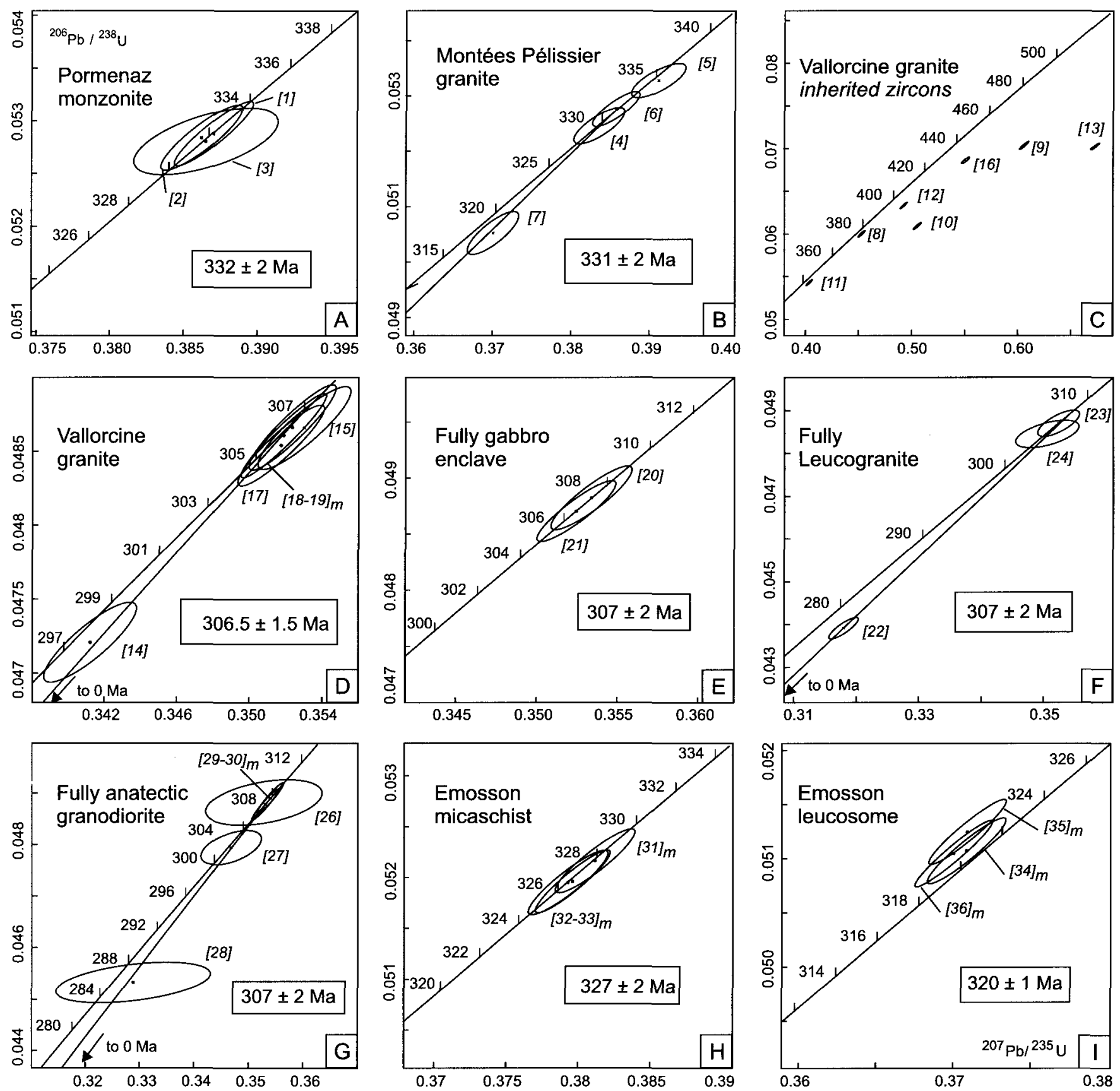

Figure $5 \quad(5 \mathrm{~A}-\mathrm{I}){ }^{207} \mathrm{~Pb} /{ }^{235} \mathrm{U}$ versus ${ }^{206} \mathrm{~Pb} /{ }^{238} \mathrm{U}$ Concordia diagrams for the dated samples; fraction numbers refer to Table 2, the $\mathrm{m}$ index stands for monazite analysis (otherwise zircon), ellipses are 2-sigma errors and the preferred ages are framed. See text for discussion.

Zircon and monazite were extracted from a lower facies sample (VALG). Early dating attempts using large zircon fractions [8-13] revealed systematic inheritance (Tab. 2, Fig. 5C). Subsequent selection of hollow zircon prisms and monazite [14-19] yielded a well reproduced concordant age of $306 \cdot 5 \pm$ $1.5 \mathrm{Ma}$ (Fig. 5D), interpreted as the crystallisation age of the granite.

\subsection{The Montées Pélissier granite}

The Montées Pélissier granite is a vertical $3 \mathrm{~km}$-long by $500 \mathrm{~m}$ wide sheet-like pluton located at the SW end of the Aiguilles Rouges massif (Fig. 1) and in tectonic contact with its country-rocks. A transpressive regime induced subhorizontal movements with extreme elongation, subsequently reoriented into subvertical displacements (Dobmeier 1998). The granite intruded syntectonically along ductile shear-zones during the transcurrent stage and recorded the subsequent vertical movements during cooling (Dobmeier 1996). Primary magmatic flow fabrics are mostly superimposed by low-T ductile to brittle deformation.

The Montées Pélissier intrusion is a fine-grained foliated monzogranite, which hosts rare biotite-rich restites, mafic microgranular enclaves and biotite-bearing lamprophyres (Tab. 1). It is a peraluminous granite with $\mathrm{A} / \mathrm{CNK}$ values between 1.17 and 1.27 ; but primary muscovite is scarce and the mean representative point of its zircon morphological population plots at the limit between peraluminous and calcalkaline granite fields in the typological grid of Pupin (1988) (Figs 3 and 4). Four zircon fractions [4-7] were selected from a representative sample (MPEL) (Tab. 2). Three hollow needles [6] yielded a perfectly concordant age of $331 \pm 2 \mathrm{Ma}$, whereas [4] and [7] record a slight lead loss, but are collinear with [6] 
(Fig. 5B). On the other hand, [5] contains a small inherited component. Relying on the concordant data, we consider that the Montées Pélissier granite crystallised at $331 \pm 2 \mathrm{Ma}$.

\subsection{The Pormenaz monzonite}

The Pormenaz pluton is located close to the Montées Pélissier granite, in the SW part of the Aiguilles Rouges massif (Fig. 1) (Laurent 1967). It is a $1.4 \times 2.5 \mathrm{~km}$ porphyritic funnelshaped mass in vertical cross section, and intruded within amphibolite-facies metamorphic rocks and Lower Carboniferous metagraywackes on the western side (Délitroz \& Fellay 1997). At the lowest exposure level, the $150 \mathrm{~m}$-wide intrusion is increasingly deformed towards its eastern margin and ends with a $45 \mathrm{~m}$-wide mylonitic zone limited by a subvertical $\mathrm{N}-\mathrm{S}$-striking transpressive fault, similar to that which controlled the Montées Pélissier intrusion (Dobmeier \& Von Raumer 1995). A moderately dipping magmatic foliation is recorded in the upper part of the pluton. The funnel shape and internal structures of the intrusion suggest a syntectonic emplacement of the magma and post-crystallisation mylonitic deformations along a long-lasting dextral transpressive fault. The Pormenaz monzonite was subsequently brought to surface level and covered by autochthonous Upper Carboniferous sediments.

The main facies is a porphyritic to equigranular monzonite with large pink or white K-feldspar megacrysts (up to $4 \mathrm{~cm}$ ) in a dark grey-green amphibole-rich matrix (Tab. 1). Euhedral crystals of brown sphene $(\leq 1.5 \mathrm{~mm})$ are clearly visible on hand specimen. A marginal facies is finer grained and homogranular, whereas minor aplitic dykes and leucocratic monzogranitic rocks occur in the upper levels of the intrusion. Characteristic minerals are sphene, $\mathrm{Mg}$-rich hornblende and biotite, often retrogressed into chlorite. Plurimetric bodies of durbachites (Holub 1977; Rock 1991) are found as dark-green, equigranular, magmatic enclaves.

The Pormenaz monzonite is characterised by high to very high concentrations in LILE like $\mathrm{K}, \mathrm{Rb}, \mathrm{Ba}, \mathrm{Sr}$, in $\mathrm{Mg}$ and transition elements like $\mathrm{Cr}$, $\mathrm{Ni}$ and $\mathrm{V}$, and in incompatible elements like LREE, $\mathrm{Zr}$ and $\mathrm{Th}$. Conversely, $\mathrm{Ca}$ is relatively low in this range of $\mathrm{SiO}_{2}$ content. REE are strongly fractionated without substantial Eu anomaly. The durbachitic enclaves have the same chemical characteristics as the monzonites, reminiscent of lamprophyres.

Zircon morphology shows a contrasted distribution, as compared with peraluminous granites (Figs 3 and 4). High A and T mean indices place this intrusion in the overlapping portion of the calc-alkaline and alkali-calcic granite fields of the typological grid of Pupin (1988), whereas classic $\mathrm{Mg}-\mathrm{K}$ suites often plot in the middle of the calc-alkaline field (e.g. Debon et al. 1998). Three zircon fractions [1-3] were isolated from a monzonite sample (PORM) (Tab. 2). All three yielded the same perfectly concordant age of $332 \pm 2 \mathrm{Ma}$ (Fig. 5A), interpreted as the crystallisation time of the intrusion.

\subsection{The Mont Blanc granite}

The Mont Blanc granite is located in the Mont Blanc massif, which was about $20 \mathrm{~km}$ further E from the Aiguilles Rouges massif before the Alpine orogeny. It is a foliated, porphyritic monzo- to syenogranite with $\mathrm{K}$-feldspar megacrysts and $\mathrm{Fe}-$ rich biotite as the only mafic mineral (Marro 1988; Bussy 1990). It hosts numerous mafic microgranular enclaves, calcalkaline micromonzodioritic stocks and synplutonic dykes of mantle origin, which record magma mingling processes (Bussy 1990). The Mont Blanc granite is a metaluminous, ferro-potassic, alkali-calcic intrusion characterised by high $\mathrm{K}$, $\mathrm{Y}, \mathrm{Zr}$ contents and $\mathrm{Fe} / \mathrm{Mg}$ ratios, and a low ${ }^{87} \mathrm{Sr} /{ }^{86} \mathrm{Sr}$ initial isotopic ratio of 0.705 (Bussy et al. 1989). Zircon morphology shows an extreme typology with very high $\mathrm{A}$ and $\mathrm{T}$ indices, typical of alkaline granites (Figs 3 and 4). Zircon U-Pb dating of the Mont Blanc granite (Bussy \& Von Raumer 1993 ) yielded an intrusion age of $303 \pm 2 \mathrm{Ma}$.

\section{Magma sources and timing of events}

\subsection{The magnesio-potassic magmatism}

The Pormenaz monzonite has all the characteristics of $\mathrm{Mg}_{-}$ K-rich magmatic suites ( \pm shoshonitic diorites, monzonites, granites, syenites), as defined by Rossi \& Cocherie (1995). Typical features are the ubiquity and abundance of sphene, $\mathrm{K}$-feldspar megacrysts, the presence of high- $\mathrm{Cr}$ and $\mathrm{Ni}$ basic enclaves of lamprophyric affinity, and high to very high contents of $\mathrm{K}, \mathrm{Mg}, \mathrm{Rb}, \mathrm{Sr}, \mathrm{Ba}, \mathrm{Cr}, \mathrm{Ni}, \mathrm{LREE}, \mathrm{Th}, \mathrm{Zr}$ in all petrographic facies. $\mathrm{Mg}-\mathrm{K}$ magmatic suites are well represented in the European Variscan belt, including Corsica, the External Crystalline Massifs, the French Massif Central, and the Vosges and Bohemian massifs (see review in Debon et al. 1998). All available ages point to almost simultaneous intrusion between $343 \mathrm{Ma}$ and $330 \mathrm{Ma}$, in keeping with the $332 \mathrm{Ma}$ age of the Pormenaz monzonite. This episode seems always to be shortlived, commonly syntectonic within major shear-zones and early in the local magmatic activity, and may be accompanied by anatectic peraluminous melts. The Pormenaz monzonite intruded at shallow depth along the transpressive border fault of a small Visean volcano-sedimentary basin (Fig. 1), a situation identical to that observed in the Vosges (Schaltegger et al. 1996) and the Aar massif (Schaltegger \& Corfu 1995). The development of these basins attests to local extensional zones (first extensional event of Burg et al. 1994) within an overall transpressive regime, favouring the high-level emplacement of magmas.

The lamprophyre-type mafic magmatism systematically associated with the $\mathrm{Mg}-\mathrm{K}$ granitoids, $\mathrm{Sr}, \mathrm{Nd}$ and $\mathrm{Hf}$ isotopic data (e.g. Schaltegger \& Corfu 1992; Cocherie \& Rossi 1995; Janoušek et al. 1995; Schaltegger et al. 1996; Gerdes et al. 1998a) and episodic zircon inheritance all point to an essentially high-K lithospheric mantle source, metasomatised during an earlier subduction event, mixed with variable amounts of lower crustal material.

\subsection{The peraluminous magmatism}

Peraluminous melts were generated throughout the Late Carboniferous magmatic activity of the Aiguilles Rouges massif, either as in-situ or short-range mobilised leucosomes, or as larger, syntectonic intrusions along major dextral strike-slip faults. All these melts have an indisputable crustal origin, documented by their Al-rich mineralogy, high restite content, zircon typology and oxygen isotopes. Peraluminous granites can be separated into muscovite-bearing and cordierite-bearing intrusions, respectively, which form under contrasting physical conditions (Barbarin 1996). Muscovitebearing granites are characterised by primary muscovite, low biotite contents, a scarcity of both restites and mafic microgranular enclaves, whole-rock chemical compositions close to the granitic minimum melt and a systematic association to shear zones. According to Barbarin (1996), they form under wet, relatively low temperature anatexis, mostly within fault zones where fluids are circulating. Conversely, cordieritebearing granites such as the Vallorcine and Fully intrusions, are higher temperature melts, richer in biotite, restites and mafic enclaves, and form under drier and higher temperature conditions through dehydration melting of biotite. In the latter case, partial melting would be triggered by the addition of heat supplied by mantle-derived magmas, as documented by 
the hosted mafic magmatic enclaves (e.g. Fully gabbros). The Montées-Pélissier intrusion is of intermediate type; although it contains muscovite, its rather low $\mathrm{SiO}_{2}$ content (67-$68 \mathrm{wt} \%$ ), the relative abundance of biotite and the presence of lamprophyric dykes make it closer to cordierite-bearing than to muscovite-bearing granites. All peraluminous intrusions within the Aiguilles Rouges massif are thus of high temperature type and are associated with mantle-derived melts. The latter evolve from shoshonitic to normal calc-alkaline type with time, i.e. from the $332 \mathrm{Ma}$ Pormenaz durbachites and Montées Pélissier lamprophyric dykes to the $307 \mathrm{Ma}$ Fully gabbros.

\subsection{The ferro-potassic magmatism}

Although not part of the Aiguilles Rouges massif, the nearby Mont Blanc granite is of interest as the youngest intrusion in the area $(303 \mathrm{Ma})$. It belongs to the so-called ferro-potassic, or alkali-calcic, or low-mg-number suites (Debon \& Lemmet 1999). These suites are characterised by acid-basic bimodal magmas, high $\mathrm{K}$ contents (alkali-calcic suites), $\mathrm{Fe} / \mathrm{Mg}$ ratios and ' $\mathrm{A}$ ' zircon indices. Using the $\mathrm{Fe} / \mathrm{Mg}$ ratio as a discriminating factor, Debon \& Lemmet (1999) showed that the Variscan Fe-K granites (e.g. Aar, Gotthard) emplaced within a welldefined period of time between $305 \mathrm{Ma}$ and $295 \mathrm{Ma}$, in the same way as did $\mathrm{Mg}-\mathrm{K}$ granites between $340 \mathrm{Ma}$ and $330 \mathrm{Ma}$. These authors ascribe the change in the $\mathrm{Fe} / \mathrm{Mg}$ ratio between the two suites to a combination of several interacting factors, including the evolving nature of the magma sources, the physical and chemical conditions of melting $\left(\mathrm{P}, \mathrm{T}, \mathrm{PH}_{2} \mathrm{O}, \mathrm{fO}_{2}\right)$, and the geotectonic settings. According to Bonin et al. (1998), $\mathrm{Fe}-\mathrm{K}$ suites document the onset of the post-orogenic stage of a Wilson cycle. They would ultimately originate in an asthenospheric mantle source, replacing the older orogenic lithospheric mantle. Granitic melts would result from crustal assimilation and contamination of mantle-derived magmas, as well as [biotite + plagioclase] fractionation under relatively high water pressures.

\subsection{Carboniferous tectono-magmatic evolution in the Aiguilles Rouges-Mont Blanc massifs}

The Carboniferous tectono-magmatic evolution of the Aiguilles Rouges-Mont Blanc area can be synthesised in the following way:

(a) Peak T metamorphic conditions are recorded at $327 \mathrm{Ma}$ (peak $\mathrm{P}$ is undated, but is probably older) in the Emosson metapelites and isothermal decompression melting at $320 \mathrm{Ma}$. This relatively short time-span requires fast uplift rates, accommodated through active tectonic exhumation. According to Thompson \& Connolly (1995), decompression melting within the sillimanite-andalusite metamorphic facies cannot occur through simple erosional uplift. Exhumation was thus already active in the Upper Visean, shortly after the transpressive episode recorded by the Montees Pélissier granite. This is confirmed by ${ }^{39} \mathrm{Ar} /{ }^{40} \mathrm{Ar}$ cooling ages as old as $337-331 \mathrm{Ma}$ measured on white micas from gneisses adjacent to the Montées Pélissier granite (Dobmeier 1998). The former nappe stacking which let to the crustal thickening is documented by microstructures (Dobmeier 1996), but its timing is unknown. In the adjacent Belledonne massif, nappe stacking did not occur before the Visean (Guillot \& Ménot 1999) and decompression melting followed quickly during the Westphalian, a timing very similar to that of the Aiguilles Rouges massif.

(b) The 332 Ma Pormenaz monzonite intruded along a highstrain, NNE-SSW-trending mylonitic transcurrent fault, which also controlled the position of the adjacent Visean detrital basin. Considering the ultimate mantle origin of these melts, and their usual syntectonic character in the Variscides, it is inferred that this transcurrent fault zone was a major crustalto lithospheric-scale structure, which tapped deep-seated magma chambers or possibly enhanced melting processes. The nearby and contemporaneous Montées Pélissier granite intruded in a similar context. Fluids circulating along the transcurrent fault might have favoured melting of crustal lithologies, triggered by heat transfer from the mantle magmas (presence of lamprophyric dykes).

(c) The next recorded event is the simultaneous formation of the Upper Carboniferous detrital basin of Salvan-Dorénaz, starting at $308 \mathrm{Ma}$ (Capuzzo \& Bussy 1999), and the $307 \mathrm{Ma}$ magmatic pulse of cordierite-bearing granites. The Vallorcine granite intrudes syntectonically along the border fault of the basin, which is again considered as a major crustal-scale structure. Erosion was very active and thick coarse deposits accumulated in the basin at least until 295 Ma (Capuzzo \& Bussy 1999). This is interpreted as evidence for continued tectonic exhumation in the latest Carboniferous in an essentially transcurrent to transtensional, rather than extensional, regime. In that context, the sedimentary trough could have formed as a kind of pullapart structure or half-graben in the case of oblique sliding (intermediate between normal and transcurrent faulting) along the border fault. Granodioritic cordierite-bearing melts require temperatures well above $800^{\circ} \mathrm{C}$ to form (e.g. PatiñoDouce \& Harris 1998). Such conditions were not reached through regional metamorphism in the lower-middle crust and required additional heat, most probably supplied by the associated mafic mantle magmatism. The lower crustal magma sources were tapped by the deep transcurrent faults along which progressive restite unmixing and crystal fractionation occurred.

(d) In the nearby Mont Blanc massif, the larger post-tectonic $303 \mathrm{Ma}$ Mont Blanc acid-basic association intrudes within a pull-apart structure in a continued transcurrent to transtensive regime. The inferred mantle source is different from that of the Pormenaz monzonite.

The Carboniferous tectono-magmatic evolution outlined above is virtually identical to that observed in the other External Crystalline Massifs and adjacent areas, with minor differences in the timing of events (e.g. Schaltegger 1997; Debon \& Lemmet 1999). More generally, it is in good accordance with the overall Carboniferous evolution of the internal Variscides (e.g. Burg et al. 1994; Rey et al. 1997), considered as a period of post-collisional readjustment of a thickened continental crust.

\section{Magma evolution and geodynamic context}

The Carboniferous magmatic evolution depicted above must be considered as a response to global geodynamic changes at the largest scale during the Variscan orogeny. If there is a consensus on the collisional nature of the Variscan belt, crust thickening processes and subsequent restoration to normal thickness, other points are still matters of debate, e.g. the heat source responsible for the late Carboniferous hightemperature anomaly and associated granites, the timing and geometry of collisional events and associated subduction zones, the ultimate cause for the widespread late orogenic extension of the belt.

\subsection{The heat problem}

The nature of the heat source necessary to generate the large volumes of crustal-derived intrusive magmas of the lateVariscan orogeny has long been debated. Large magma volumes of granodioritic composition require temperatures well above $800^{\circ} \mathrm{C}$ and large-scale dehydration melting 
reactions of biotite. Two contrasting heat supply mechanisms, probably both active, are currently invoked: an (almost) purely crustal origin through thickening and radioactive decay, and basaltic underplating.

Partial melting through purely crustal heat supply has recently been proposed and modelled by Gerdes et al. (1998b), following observation that in the southern Bohemian massif, $65,000 \mathrm{~km}^{3}$ of crustal-derived granites emplaced between $330 \mathrm{Ma}$ and $320 \mathrm{Ma}$, without any substantial visible magmatic activity of the mantle. According to their model, a total thickening of $50 \mathrm{~km}$ of fertile, metasedimentary units, could heat up through purely radiogenic heat production within a time span of $20-40 \mathrm{Ma}$ and potentially produce up to $80,000 \mathrm{~km}^{3}$ melt trough $35-50 \mathrm{vol} \%$ dehydration melting of the middle crust $(27-35 \mathrm{~km})$ at temperatures of $870-935^{\circ} \mathrm{C}$. This model, which requires complete duplication of the crust over hundreds of $\mathrm{km}$ and highly fertile metasediments, is hardly compatible with the External Crystalline Massif geological context and the very short-lived character and small volumes of the magmatic pulses.

On the other hand, basalt underplating has long been invoked for the production of granitic magmas in postcollisional extensional tectonic regimes, such as in the Basin and Range Province of Western USA, often cited as a reference for the Variscides (e.g. Lorenz \& Nicholls 1984; Ménard \& Molnar 1988; Schaltegger \& Corfu 1995). Intrusion in the lower crust of mantle-derived mafic magmas as layered maficultramafic complexes, and corresponding granulite-facies metamorphism are well documented (e.g. Pin \& Vielzeuf 1983). Different mechanisms might be inferred for the generation of basaltic melts, such as slab-breakoff of a subducted oceanic lithosphere (Von Blanckenburg \& Davies 1995), subduction of an active mid-oceanic ridge (Stampfli 1996), or lithospheric mantle erosion and/or delamination with influx of hot asthenospheric mantle, in response to post-orogenic re-equilibration of a thickened lithosphere (e.g. Rey et al. 1997).

\subsection{Mechanisms of late-orogenic extension}

Two ultimate mechanisms are put forward to explain lateVariscan extension, based on contrasting Late-Palaeozoic geodynamic reconstructions. In a classical approach, the Variscan belt has been considered as resulting from a monocyclic and long-lasting continental collision with major thickening, over a wide front between Laurasia and Gondwana (see Rey et al. 1997 and references therein). As a consequence, the very thick continental crust would collapse after weakening through thermal relaxation. Extension would result through lateral pressure gradients, enhanced by the progressive thinning of the lithospheric mantle and/or reduction of compressional forces.

Alternative models favour more complex and evolving collisional events, and emphasise subduction-related back-arc extensional processes. Faure et al. (1997) ascribe LateDevonian extension in the Variscides to back-arc extension and rifting of the S-dipping subduction of the Rheic oceanic crust underneath the Saxo-Thuringian front; Stampfli et al. (2000) ascribe the Ibero-Armorican arc to the roll-back of the same slab (Fig. 6). Their reconstruction favours a rather narrow collisional front between Gondwana and Laurasia, and keeps the SE flank of the Variscan belt open to the Palaeotethys ocean with a strongly oblique, mostly transcurrent NE subduction of the latter under the accreted margin of Laurasia (Fig. 6). As a consequence, continent-continent hypercollision would be limited, as well as crustal thickening and associated gravitational mechanisms. Instead, the Palaeotethys mid-ocean ridge would be subducted underneath the Variscan belt between c. $400 \mathrm{Ma}$ and $300 \mathrm{Ma}$, inducing an updoming and extension of the overlying continental crust with basalt underplating. Slab-breakoff of the western Palaeotethys oceanic crust would be responsible for the large Permian rifting in Western Europe (Stampfli 1996). This situation would actually be very similar to that of the Pacific ridge subduction beneath the Californian coast adjacent to the Basin and Range Province. Surprisingly, this mechanism is hardly considered in the

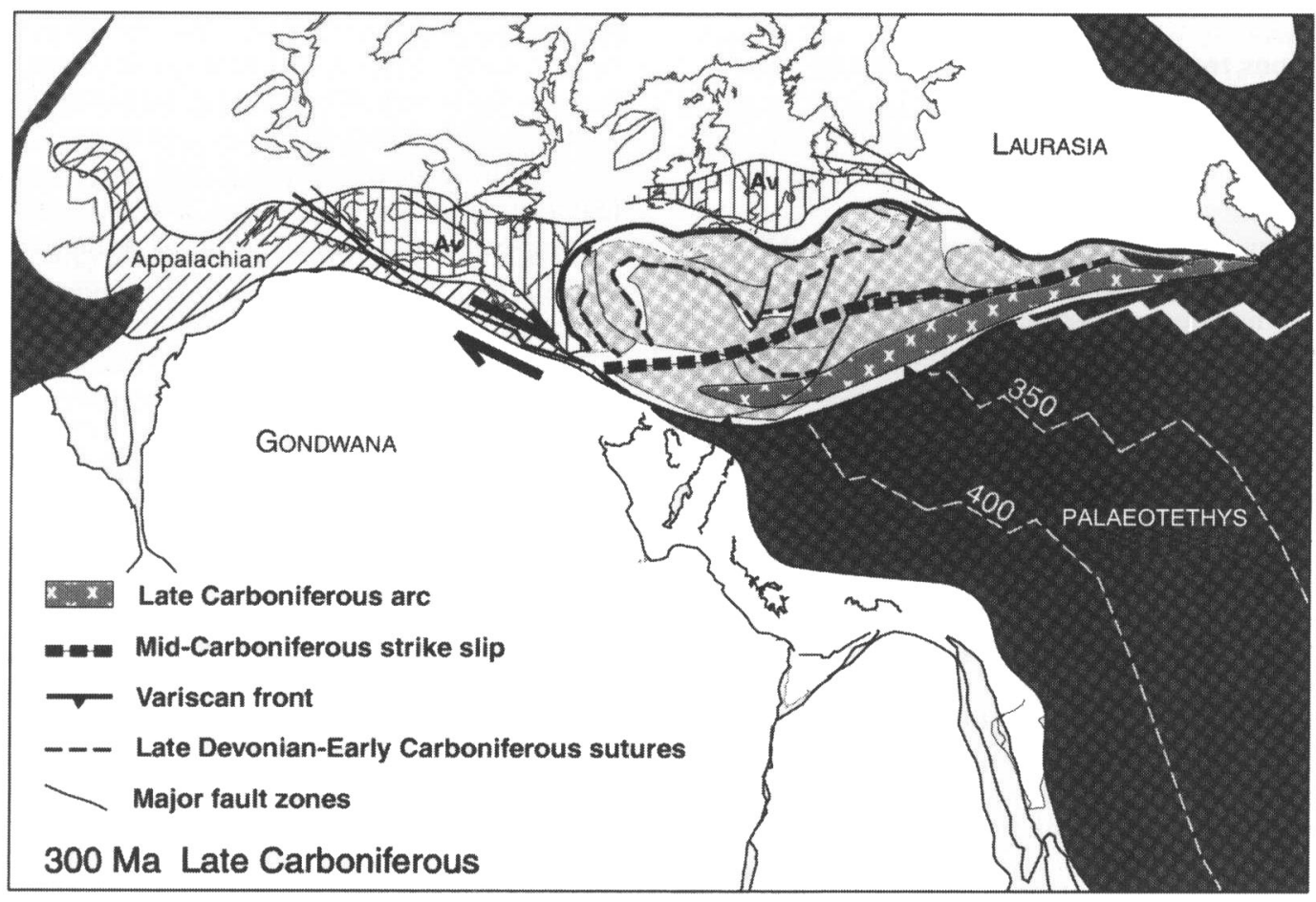

Figure 6 Palinspastic map of the Variscides in Late Carboniferous, simplified from Stampfli et al. (2000) Av: Avalonia. Individual Hun terranes within the Variscan belt (light grey pattern) are not distinguished. Oblique collision of Gondwana with Laurasia induced dextral transcurrent movements along the suture zone and within the accreted Hun tcrranes. The Palaeotethys western margin is essentially transcurrent at that time, but slab breakoff $\mathrm{S}$ of the subducting active margin is expected to occur, promoting widespread Permian extension and rifting in the Variscan belt. 
literature for the formation of this province, authors instead favouring gravitational collapse processes.

\subsection{Magma evolution}

It is unlikely that magma typology alone will allow a clear discrimination between subduction-related and collapse-related settings, in the sense that back-arc extension within a thickened and highly heterogeneous accreted belt, possibly with internal oceanic sutures, will not generate typical calc-alkaline arctype magmas. Heterogeneity within the composite accreted belt and associated mantle lithosphere will yield variable and ambiguous geochemical and isotopic signatures. Whatever the ultimate triggering mechanism for the Late-Variscan extension, field evidence points to collisional events and indisputable continental lithosphere subduction at the Laurasia-Gondwana boundary. In this context, the magmatic evolution recorded in the External Crystalline Massifs and adjacent areas can be interpreted in the following way.

The 340-330 Ma Mg-K magmatism has a mixed lithospheric mantle and lower crustal origin. These syntectonic melts are associated with major transcurrent faults and seem to constitute an 'isochron belt' throughout Europe (Rossi \& Cocherie 1995; Von Raumer 1998), although the exact geometry of the latter is unknown due to potential Late-Carboniferous transcurrent displacement. This belt probably reflects a major geotectonic structure, where partial melting of the lithospheric mantle and lower crust would have been favoured for a short time (Visean extension), possibly controlled by lithosphericscale transcurrent faults. Such a structure could be the position of maximum depth of the subducted continental lithosphere (orogenic root), which would have experienced thermal erosion leading to buoyancy and subsequent decompression melting of the remaining lithosphere (Schaltegger 1997) or, in the model of Stampfii et al. (2000), the subducted mid-ocean Palaeotethys ridge (Fig. 6), which would have melted the overlying lithospheric mantle.

The subsequent magmatic pulses reflect an increasing involvement of mid-crustal sources mixed with nonlamprophiric mafic sources. This illustrates enhanced heating of the continental crust in parallel to an evolving lithospheric mantle, which progressively recovers a normal thickness and composition with advection of asthenospheric material (in response to the slab-breakoff of the western Palaeotethys oceanic crust?). Basaltic melts are generated within the upwelling asthenosphere and pond at the crust-mantle boundary, supplying heat to an exhuming continental crust warmed by radioactive decay. Crustal melts are generated through massive dehydration melting at various levels and mix with mantle material. In-situ anatexis at higher crustal levels occurs through isothermal decompression melting.

Looking at more internal parts of the Alps, a general tendency to younger intrusion ages towards the SE is quite clear (Bussy \& Cadoppi 1996), from $340 \mathrm{Ma}$ in the External Crystalline Massifs to $270 \mathrm{Ma}$ in the internal Penninic and Southern Alps. This migration of the magmatic activity, with concomitant evolution towards more alkaline granites and contemporaneous intrusion of gabbros in the lower crust along continental-scale fault zones (Hermann et al. 1997; Bussy et al. 1998; Bonin et al. 1998) reflects the increasing underplating effect of an upwelling asthenospheric mantle at the base of a thinning and stretching continental crust, which will finally disrupt at the time of the Neotethys opening.

\section{Conclusion}

High-precision U-Pb dating of zircon and monazite allowed discrimination of three short-lived and bimodal magmatic pulses in the Aiguilles Rouges-Mont Blanc area. They intruded syntectonically along dextral shear-zones in an overall transcurrent tectonic regime, which lasted at least over $30 \mathrm{Ma}$, switching from transpressive to transtensive with time. Concomitant tectonic exhumation led to isothermal decompression melting and local melt segregation within mid-crustal levels, as well as active erosion at the surface level. Magma compositions evolve through time, reflecting a change in both crustal and mantle sources. Magma mixing processes are the rule. Crustal sources evolve from lower- to mid-crustal lithologies with progressive heating of the continental crust, whereas mantle sources evolve from a formerly metasomatised lithospheric mantle to more pristine asthenospheric sources. At a larger scale, this ends up during the Permian with alkaline acid-basic coeval magmatism. This overall evolution is interpreted in a scenario of post-collisional restoration to normal size of a thickened continental lithosphere, characterised by late-orogenic extension. The ultimate mechanism triggering extension is ambiguous.

\section{Acknowledgements}

The results presented in this paper were obtained during a project financially supported by the Swiss National Science Foundation (project no 21-45650.95), which is gratefully acknowledged. This work benefited from unpublished data or samples of P. Bovay, P. Brändlein, D. Délitroz, R. Fellay and N. Meisser, as well as fruitful discussions with N. Capuzzo, F. Corfu, C. Dobmeier, J.L. Epard, U. Schaltegger, and especially G. Stampfli. We also thank M. Faure and L. Barbero for their constructive reviews and suggestions, as well as T. Krogh and D. Davis (Royal Ontario Museum) for opening their laboratory to F.B.

\section{References}

Barbarin, B. 1996. Genesis of two main types of peraluminous granitoids. Geology 24, 295-8.

Bonin, B., Brändlcin, P., Bussy, F., Desmons, J., Eggenberger, U., Finger, F., Graf, K., Marro, C., Mercolli, F., Oberhänsli, R., Ploquin, A., von Quadt, A., von Raumer, J., Schaltcgger, U., Steyrer, H. P., Visonà, D. \& Vivier, G., 1993. Late Variscan magmatic evolution of the Alpine Basement. In Von Raumer, J. F. \& Neubauer, F. (eds) Pre-Mesozoic Geology in the Alps, 171-201. Berlin: Springer.

Bonin, B., Azzouni-Sekkal, A., Bussy, F. \& Ferrag, S. 1998. Alkalicalcic to alkaline post-collision granite magmatism: petrologic constraints and geodynamic settings. Lithos $\mathbf{4 5}, 45-70$.

Bovay, P. 1988. Pétrographie et géochimie d'une association de roches acides et basiques, Massif cristallin de Fully (Valais). Unpublished Diploma work, Lausanne.

Brändlein, P. 1991. Petrographische und geochemische Characteristika des Vallorcine-Granits, Aiguilles Rouges-Massiv (Westalpen, Schweiz). Unpublished Ph.D. Thesis, Erlangen.

Brändlein, P., Nollau, G., Sharp, Z. \& von Raumer, J., 1994. Petrography and geochemistry of the Vallorcine granite (Aiguilles Rouges massif, Western Alps). Schweizerische Mineralogische und Petrographische Mitteilungen 74, 227-43.

Burg, J.P., Van Den Dricssche, J. \& Brun, J.P. 1994. Syn- to postthickening extension in the Variscan belt of Western Europe: modes and structural consequences. Géologie de la France 3, 33-51.

Bussy, F. 1990. Pétrogenèse des enclaves microgrenues associées aux granitö̈des calc-alcalins: example des massifs varisque du Mont Blanc (Alpes occidentales) et miocène du Montc Capanne (Ile d'Elbc, Italic). Ph.D. Thesis, Mémoires de Géologie (Lausanne) 7.

Bussy, F., Schaltegger, U. \& Marro. C. 1989. The age of the Mont Blanc granite (Western Alps): a hetcrogeneous isotopic system dated by $\mathrm{Rb}-\mathrm{Sr}$ whole rock determinations on its microgranular enclaves. Schweizerische Mineralogische und Petrographische Mitteilungen 69, 3-13. 
Bussy, F., Klemens, W. P., Krogh, T. E. \& Schwerdtner, W. M. 1995. Tectonic and metamorphic events in the westernmost Grenville Province, central Ontario: new results from high-precision U-Pb zircon geochronology. Canadian Journal of Earth Sciences 32, $660-71$.

Bussy, F., Venturini, G., Hunziker, J.\& Martinotti, G. 1998. U-Pb ages of magmatic rocks of the Western Austroalpine Dent-BlancheSesia Unit. Schweizerische Mineralogische und Petrographische Mitteilungen 78, 163-8.

Bussy, F. \& Cadoppi, P. 1996. U-Pb zircon dating of granitoids from the Dora-Maira massif (western Italian Alps). Schweizerische Mineralogische und Petrographische Mitteilungen 76, 217-33.

Bussy, F. \& Hernandez, J., 1997. Short-lived bimodal magmatism at $307 \mathrm{Ma}$ in the Mont Blanc/Aiguilles Rouges area: a combination of decompression melting, basaltic underplating and crustal fracturing. Abstract, Quaderni Geodinamica Alpina e Quaternaria, Milano 4, 22. Milan: C.N.R.I.

Bussy, F. \& Von Raumer, J. 1993. U-Pb dating of Palaeozoic cvents in the Mont Blanc crystalline massif, Western Alps. Terra abtracts EUG7, Strasbourg: 382-3.

Capuzzo, N. \& Bussy, F. 1999. Volcanic Input in a Late Paleozoic Tectono-Sedimentary Basin: The Salvan-Dorénaz Basin (Southwestern Switzerland-Eastern France). EUG10, Strasbourg. Terra Abstracts 11, 297.

Cocherie, A. \& Rossi, P. 1995. Respective roles of source composition and melting conditions in the high- $K$ content of some magmas: gcochemical constraints. In The origin of granites and related rocks, $3^{\text {rd }}$ Hutton Symposium, Abstracts. U. S. Geological Survey Circular 1129, 36-7.

Dahl, P. S. 1997. A crystal-chemical basis for $\mathrm{Pb}$ retention and fissiontrack annealing systematics in U-bearing minerals, with implications for geochronology. Earth and Planetary Science Letters 150, 277-90.

Debon, F., Guerrot, C., Ménot, R.P., Vivier, G. \& Cocherie, A. 1998. Late Variscan granites of the Belledonne massif (French western Alps): a lower Visean magnesian plutonism. Schweizerische Mineralogische und Petrographische Mitteilungen 78, 67-85.

Debon, F. \& Lemmet, M. 1999. Evolution of $\mathrm{Mg} / \mathrm{Fe}$ ratios in late Variscan plutonic rocks from the External Crystalline Massifs of the Alps (France, Italy, Switzerland). Journal of Petrology 40, $1151-85$.

Délitroz, D. \& Fellay, R. 1997. Etude géologique et minéralogique de la région de Pormenaz (Haute Savoie, France). Unpublished diploma work, Lausanne.

Dobmeier, C. 1996. Die variskische Entwicklung des südwestlichen Aiguilles Rouges-Massives (Westalpen, Frankreich). Ph.D. Thesis, Mémoires de Géologie Lausanne 29.

Dobmeier, C. 1998. Variscan P-T-deformation paths from the southwestern Aiguilles Rouges massif (External massif, western Alps) and their implication for its tectonic evolution. Geologische Rundschau 87, 107-23.

Dobmeier, C., Pfeifer, H. P. \& Von Raumer, J. F. 1999. The newly defined 'Greenstone Unit' of the Aiguilles Rouges massif (western Alps); remnant of an early Palaeozoic oceanic island-arc? Schweizerische Mineralogische und Petrographische Mitteilungen 79, 263-76.

Dobmeier, C. \& Von Raumer, J. F. 1995. Significance of latestVariscan and Alpine deformation for the evolution of Montagne de Pormenaz (South-western Aiguilles Rouges massif, Western Alps). Eclogae Geologicae Helvetiae 88, 267-279.

Faure, M. 1995. Late orogenic Carboniferous extensions in the Variscan French Massif Central. Tectonics 14, 132-53.

Faure, M., Leloix, C. \& Roig, J. Y. 1997. L'évolution polycyclique de la chaîne hercynienne. Bulletin de la Société Géologique de France 168, 695-705.

Gerdes, A., Wörner, G. \& Finger, F. 1998a. Large chemical variations in the Variscan Rastenberg pluton caused by mixing enriched mantle magmas with crustal melts. Abstract, Acta Universitatis Carolinae, Geologica 42, 256.

Gerdes, A., Wörner, G. \& Henk, A. 1998b. Thermal and geochemical evidence for granite generation and HT-L.P metamorphism by crustal stacking and radiogenic heating (The Variscan Southern Bohemian masif). Abstract, Acta Universitatis Carolinae, Geologica 42, 254.

Guillot, S. \& Ménot. R. P. 1999. Nappe stacking and first evidence of Late Variscan extension in the Belledonne Massif (External Crystalline Massifs, French Alps). Geodynamica Acta 12, 97-111.

Hermann, J., Müntener, O., Trommsdorff, V., Hansmann, W. \& Picardo, G.B. 1997. Fossil crust-to-mantle transition, Val Malenco (Italian Alps). Journal of Geophysical Research 102, 20123-32.
Holdaway, M. J. 1971. Stability of andalusite and the aluminium silicate phase diagram. American Journal of Science 271, 97-131.

Holub, F. V. 1977. Petrology of inclusions as a key to petrogenesis of the durbachitic rocks from Czecheslovakia. Tschermaks Mineralogische und Petrographische Mitteilungen 24, 133-50.

Janoušek, V., Rogers, G. \& Bowes, D.R. 1995. Sr-Nd isotopic constraints on the petrogenesis of the Central Bohemian Pluton, Czech Republic. Geologische Rundschau 84, 520-34.

Kerrich, R., Allison, I., Barnett, R. L., Moss, S. \& Starkey, J. 1980. Microstructural and chemical transformations accompanying deformation of granite in a shear zone at Miéville, Switzerland; with implications for stress corrosion cracking and superplastic flow. Contributions to Mineralogy and Petrology 73, 221-42.

Krogh, T. E. 1973. A low-contamination method for hydrothermal decomposition of zircon and extraction of $\mathrm{U}$ and $\mathrm{Pb}$ for isotopic age determinations. Geochemica et Cosmochimica Acta 37, 485-94.

Krogh, T. E. 1982. Improved accuracy of U-Pb zircon ages by the creation of more concordant systems using an air abrasion technique. Geochimica et Cosmochimica Acta 46, 637-49.

Krummenacher, D. 1959. Le cristallin de la région de Fully (Valais). Schweizerische Mineralogische und Petrographische Mitteilungen $39,151-266$

Laurent, R. 1967. Etude géologique et pétrographique de l'extrémité méridionale du massif des Aiguilles Rouges (Haute Savoie, France). Ph.D. Thesis, No 1434, University of Geneva.

Lorenz, V. \& Nicholls, I.A. 1984. Plate and intraplate processes of Hercynian Europe during the Late Paleozoic. Tectonophysics $107,25-56$.

Ludwig, K. 1999. Isoplot/Ex. A Geochronological Toolkit for Microsoft Excel. Berkeley, CA: Berkeley Geochronology Center, Special Publication 1a.

Marro, C. 1988. Organisation géochimique et intrusion du granite du Mont Blanc et de deux leucogranites. Schweizerische Mineralogische und Petrographische Mitteilungen 68, 521-29.

Ménard, G. \& Molnar, P. 1988. Collapse of a Hercynian Tibetan Plateau into a Latc Palcozoic Europcan Basin and Rangc province. Nature 334, 235-7.

Paquette, J. L., Ménot, R. P. \& Pcucat, J. 1989. REE, Sm-Nd and U$\mathrm{Pb}$ zircon study of eclogites from the Alpine External massifs (Western Alps): evidence for crustal contamination. Earth and Planetary Science Letters 96, 181-198.

Patiño-Douce, A. E. \& Harris, N. 1998. Experimental constraints on Himalayan anatexis. Journal of Petrology 39, 689-710.

Pin, C. \& Vielzeuf, D. 1983. Granulites and related rocks in Variscan Median Europe: a dualistic interpretation. Tectonophysics $\mathbf{9 3}$ 47-74.

Pupin, J.P 1980. Zircon and granite petrology. Contributions to Mineralogy and Petrology 73, 207-20.

Pupin, J.P. 1988. Granites as indicators in paleogeodynamics. Rendiconti della Societa Italiana di Mineralogia e Petrologia 43 , 237-62.

Rey P., Burg, J. P. \& Casey, M. 1997. The Scandinavian Caledonides and their relationship to the Variscan belt. In Burg. J.P. \& Ford, M. (eds) Orogeny through Time, Geological Society Special Publications 121, 179-200. London: Gcological Socicty

Rock, N. M. S. 1991. Lamprophyres, Glasgow: Blackic.

Rossi, P. \& Cocherie, A. 1995 . A belt of high-K plutonic rocks related to crustal extension: evidence from the European Variscan. In The Origin of Granites and Related Rocks $3^{\text {rd }}$ Hutton Symposium, Abstracts. U. S. Geological Survev Circular 1129, 128-9.

Schaltegger, U. 1994. Unravelling the pre-Mesozoic history of Aar and Gotthard massifs (Central Alps) by isotopic dating a review. Schweizerische Mineralogische und Petrographische Mitteilungen 74, $41-52$.

Schaltegger, U. 1997. Magma pulses in the Central Variscan belt: episodic melt generation and emplacement during lithospheric thinning. Terra Nova 9, 242-5.

Schaltegger, U, Schneider, J. L., Maurin, J. C. \& Corfu, F. 1996. Precise $\mathrm{U}-\mathrm{Pb}$ chronometry of 345-340 Ma old magmatism related to synconvergence extension in the Southern Vosges (Central Variscan Belt). Earth and Planetary Science Letters 144, 403-419.

Schaltegger, U., Fanning, C. M., Günther, D., Maurin, J. C. Schulmann, K. \& Gebauer, D. 1999. Growth, annealing and recrystallization of zircon and preservation of monazite in highgrade metamorphism: conventional and in-situ isotope, cathodoluminescence and microchemical evidence. Contributions to Mineralogy and Petrology 134, 186-201.

Schaltegger, U. \& Corfu, F. 1992. The age and source of Late Hercynian magmatism in the Central Alps: evidence from precise $\mathrm{U}-\mathrm{Pb}$ ages and initial $\mathrm{Hf}$ isotopes. Contributions to Mineralogy and Petrology 111, 329-344. 
Schaltegger, U. \& Corfu, F. 1995. Late Variscan 'Basin and Range' magmatism and tectonics in the Central Alps: evidence from U-..Pb geochronology. Geodynamica Acta 8, 82-98.

Schärer, U. 1984. The effect of initial $230^{\mathrm{Th}}$ disequilibrium on young $\mathrm{U}-\mathrm{Pb}$ ages: the Makalu case, Himalaya. Earth and Planetary Science Letters 67, 191-204.

Schulz, B. \& Von Raumer, J. F. 1993. Syndeformational uplift of Variscan high pressure rocks (Val Bérard, Aiguilles Rouges, Western Alps. Zeitschrift der Deutschen Geologischen Gesellschaft 144, $104-20$

Stacey, J. S. \& Kramers, J. D. 1975. Approximation of terrestrial lead isotope evolution by a two-stage model. Earth and Planetary Science Letters 6, 15-25.

Stampfli, G. M. 1996. The Intra-Alpine terrain: a Paleotethyan remnant in the Alpine Variscides. Eclogae Geologicae Helvetiae 89, $13-42$.

Stampfli, G. M., Mosar, J., Favre, P., Pillevuit, A. \& Vannay, J. C. 2000. Permo-Mesozoic evolution of the western Tethyan realm: the Neotethys/East- Mediterranean connection. In Cavazza, W., Robertson, A. H. F. R. \& Ziegler, P. A. (eds) Peritethyan rift wrench basins and passive margins IGCP 369. Bulletin du Museum National d'Histoire Naturelle Paris (in press).

Thompson, A. B. 1990. Heat, fluids, and melting in the granulite facies. In Vielzeuf, D. \& Vidal, P. (eds) Granulites and crustal evolution, 35-57. Dordrecht: Kluwer.

Thompson, A. B. \& Connolly, J. A. D. 1995. Melting of the continental crust: some thermal and petrological constraints on anatexis in continental collision zones and other tectonic settings. Journal of Geophysical Research 100, 15565-79.

Vavra, G. \& Schaltegger, U. 1999. Post-granulite facies monazite growth and rejuvenation during Pcrmian to Lower Jurassic thermal and fluid events in the Ivrea zone (Southern Alps). Contributions to Mineralogy and Petrology 134, 403-14.

Vielzeuf, D. \& Pin, C. 1989. Geodynamic implications of granulitic rocks in the Hercynian Belt. In Daly, J. S., Cliff, R. A. \& Yardley,
B. W. D. (eds) Evolution of Metamorphic Belts, Geological Society Special Publications 43, 343-8. London: Geological Society.

Von Blanckenburg, F. \& Davies, J. H. 1995. Slab breakoff: a model for syncollisional magmatism and tectonics in the Alps. Tectonics 14, $120-31$.

Von Raumer, J. F. 1998. The Palaeozoic evolution in the Alps: from Gondwana to Pangea. Geologische Rundschau 87, 407-35.

Von Raumer, J. F., Galetti, G., Oberhänsli, R. \& Pfeifer, H. R. 1990. Amphibolites from Lac d'Emosson/ Aiguilles Rouges (Switzerland): Tholeiitic basalts at a transition zone between continental and oceanic crust. Schweizerische Mineralogische und Petrographische Mitteilungen 70, 419-35.

Von Raumer, J., Bussy, F. \& Sharp, Z. D. 1996. Lac Cornu revisited: the evolution from lower to upper crust (Aiguilles Rouges Massif, Western Alps). Schweizerische Mineralogische und Petrographische Mitteilungen 76, 120-1.

Von Raumer, J. F., Abrecht, J., Bussy, F., Lombardo, B., Mćnot, R. P. \& Schaltegger, U. 1999a. The Palaeozoic metamorphic evolution of the Alpine External Massifs. Schweizerische Mineralogische und Petrographische Mitteilungen 79, 5-22.

Von Raumer, F., Bussy, F. \& Stampfli, G. 1999b. The peri-Gondwanan origin of pre-Mesozoic basement units in the Alps, EUG10, Strasbourg. Terra Abstracts 11, 88 .

Von Raumer, J. \& Neubauer, F. 1993. Late Precambrian and Palaeozoic Evolution of the Alpine Basement an overview, In Von Raumer, J. F. \& Neubauer, F. (eds) The pre-Mesozoic geology in the Alps, 625-39. Heidelberg: Springer.

Von Raumer, J. F. \& Schwander, H. W. 1985. Garnet evolution in preVariscan pelitic rocks from the Lake Emosson area, Aiguilles Rouges Massif, Western Alps, Journal of Metamorphic Geology 3, 467-79.

Wirsing, A. 1997. Die Orthogneise des oberen Val Bérard (Aiguilles Rouges Massiv, Westalpen, Frankreich). Unpublished Ph.D. Thesis, Fribourg.

FRANÇOIS BUSSY, Earth Sciences Department, Royal Ontario Museum, Toronto, Canada; and IMP-BFSH2, UNIL, CH-1015 Lausanne, Switzerland

e-mail: francois.bussy $@$ imp.unil.ch

JEAN HERNANDEZ, IMP-BFSH2, UNIL, CH-1015 Lausanne, Switzerland

e-mail: jean.hernandez@imp.unil.ch

JÜRGEN VON RAUMER, Institut de Minéralogie, Pérolles Université, CH-1700 Fribourg,

Switzerland

e-mail: juergen.vonraumer@unifr.ch

MS received 21 September 1999. Accepted for publication 25 April 2000. 